NASA TECHNICAL MEMORANDUM

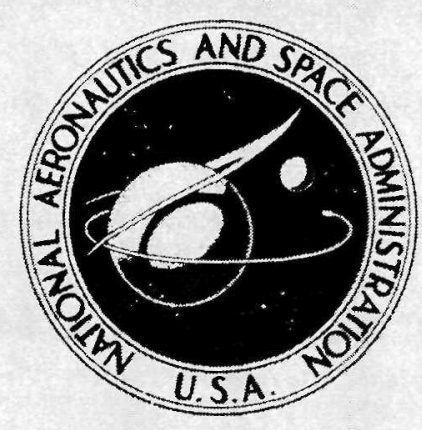

NASA TM X-2540

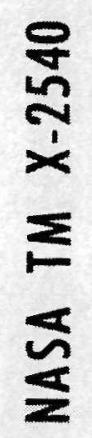

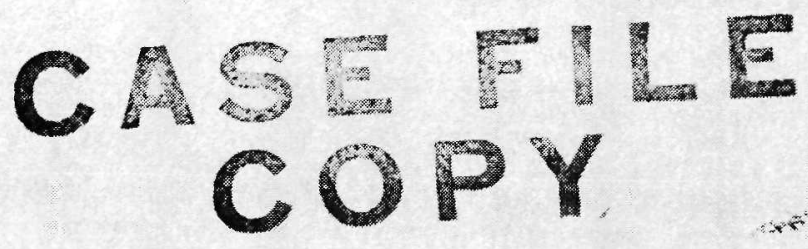

TOROIDAL TRANSFORMER DESIGN PROGRAM WITH APPLICATION TO INVERTER CIRCUITRY

by James A. Dayton, Jr.

Lewis Research Center

Cleveland, Obio 44135

NATIONAL AERONAUTICS AND SPACE ADMINISTRATION - WASHINGTON, D. C. - JUNE 1972 


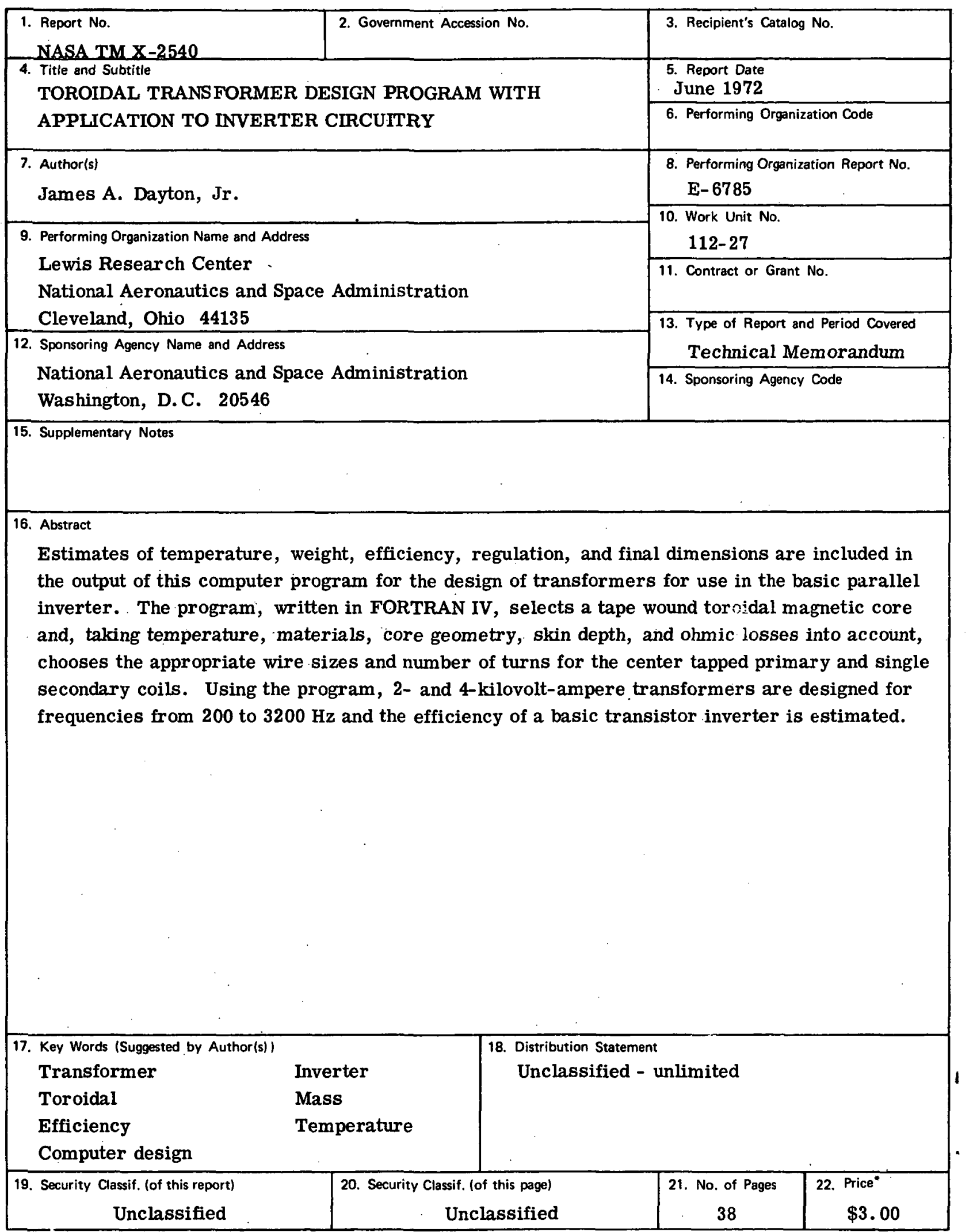

*For sale by the National Technical Information Service, Springfield, Virginia 22151 


\title{
TOROIDAL TRANSFORMER DESIGN PROGRAM WITH APPLICATION TO INVERTER CIRCUITRY
}

\author{
by James A. Dayton, Jr. \\ Lewis Research Center
}

\begin{abstract}
SUMMARY
Users of this program are relieved of most computational details, while maintaining control over most engineering decisions, in the design of toroidal transformers for use in parallel inverter circuitry.

The information supplied to the computer is the input voltage, input current, output voltage, frequency of operation, desired fill factor, maximum $I^{2} R$ loss in a coil, maximum magnetic flux density, density of the magnetic material, specific core loss, specific apparent excitation power, ambient temperature, desired current density in the windings, and relative resistance and density of the wire if a metal other than copper is used.
\end{abstract}

The computer output consists of the input and output currents and voltages, excitation current, core identification number; core weight, core loss, approximate regulation, total losses, efficiency, total mass, fill factor, ambient and operating temperatures, final height, diameter, and surface area, frequency, power lost per unit surface area, and, for each coil, the number of turns, size of wire, number of parallel windings, resistance, power dissipated, and mass.

The program contains information on 90 sizes of magnetic cores, equally divided into two groups, and 48 sizes of wire. If this selection is inadequate, the program prints out an appropriate error symbol.

The program is applied to the design of 2- and 4-kilovolt-ampere transformers and, over a range of frequency from 200 to 3200 hertz, a class of transformers of nearly equal efficiency is designed. The variation in characteristics of transformers wound on heavy and light cores is also examined.

Pre-execution time on the IBM 7094 is less than 0.5 minute and execution time is approximately 0.0011 minute per transformer. 


\section{INTRODUCTION}

Electrical power requirements in spacecraft are frequently met by the use of inverter circuits that turn direct into alternating current. In most inverter circuits, the transformer is the heaviest component and usually accounts for a significant fraction of the power loss. Therefore, careful attention to transformer design can have an important effect on system weight and efficiency, but, because transformer calculations tend to be tedious and time consuming, a detailed analysis of the effects of various parameters can be a formidable task.

To meet this challenge, computer technology was first applied to transformer design by Williams, Abetti, and Magnusson (ref. 1) in 1953. Numerous authors have treated the subject since then; much of this work being summarized in a monograph by Kusko and Wroblewski (ref. 2) in 1969. A computer program for design of toroidal transformers with tape wound cores was written by Hopper (ref. 3) in 1969.: However, this earlier work simply determines the core and wire sizes and the number of turns per winding; it does not take skin depth or core weight and reluctance into account, nor does it compute transformer weight, efficiency, operating temperature, and regulation.

The program developed in this report includes these effects and performs the computations required in the transformer design. However; the number of specifications. that must be supplied by the user allows for considerable flexibility and for the exercise of engineering judgement. Furthermore, the speed of the program makes it possible to run a great many cases, economically determining the effect of various parameter changes.

The transformers considered here have a center tapped primary coil surrounded by a single secondary coil on a tape wound toroidal core, as shown in figure 1 . The program contains the specifications of 90 toroid sizes, : equally divided into two groups, and 48 round wire sizes. The user determines the magnetic core and wire materials to be used. The rationale behind the division of the magnetic core library into heavy or lowgain cores and light or high-gain cores is discussed in detail in appendix A.: The power

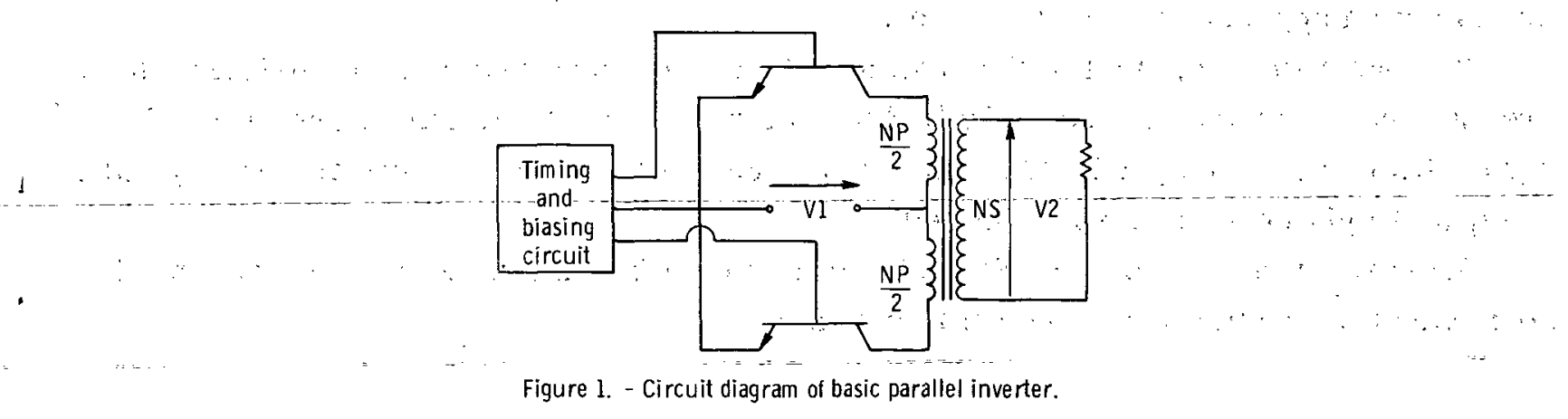


ratings of transformers that can be designed by this program depend on the materials used and the frequency of operation but in general extend from a few volt-amperes to the low kilovolt-ampere range. To design systems for power levels higher than a few kilovolt-amperes, either data on larger cores may be placed in the program library or the system may be made up of several modules.

Taking into consideration such parameters as the desired current density, desired fill factor, the ohmic power consumption, skin depth, and ambient temperature, the program produces a statement of the physical description of the transformer and computes its weight, efficiency, regulation, and operating temperature.

The model used for the estimation of operating temperature is that of a transformer suspended in a vacuum from leads that cannot conduct heat. The only mechanism of heat loss is radiation from the entire outer surface to a sink at a constant ambient temperature.

Two numerical examples, a 2.0 and a 4.0 kilovolt-ampere transformer, are contained in this report. A detailed analysis is made of the variation in mass, efficiency, and operating temperature functions of the frequency, current density, fill factor, and materials. An estimate of the performance of inverters using these transformers is illustrated by including the effect of frequency on the efficiency of typical transistors... for this power level.

\section{SYMBOLS}

A

$\mathrm{AC}$

$\mathrm{AD}$

AWT

$\mathrm{BD}$

BMAX

BUSED

CMPA

CORWAT

$\mathrm{CU}$

CUREX program indicator, if $\mathrm{A}=0$ the metal used in the transformer coil is copper, if another metal is used $A=1.0$

cross sectional core area, $\mathrm{cm}^{2}$ inside diameter of toroid after primary winding is applied, in.

wire cross sectional area including insulation, cir. mils

inside diameter of toroid after secondary winding is applied, in.

specified magnetic flux density, G

actual magnetic flux density, G

inverse current density, (cir. mils/A)

mass of magnetic core, $\mathrm{kg}$

symbol indicating to program when copper wire is to be used; $C U=1.0$ if copper is used, if another metal is used $\mathrm{CU}=0$ 
CUR1 current delivered to transformer by source, A

CUR2 current delivered by transformer to load, A

DENSITY density of core material, (lb/in. ${ }^{3}$ )

DITC inside diameter of core box, (in.)

$\mathrm{e}_{1} \quad$ instantaneous voltage supplied by source, $\mathrm{V}$

EFISH transformer efficiency

F frequency, $\mathrm{Hz}$

FF desired fill factor

FHTT height of wound toroid, $\mathrm{cm}$

FIL1 fraction of core window area filled by primary winding

FIL2 fraction of core window area filled by secondary winding

FILF fraction of core window area filled by both windings

FOD outer diameter of transformer, $\mathrm{cm}$

HTT height of core box, in.

$\mathrm{I}_{\mathrm{B}} \quad$ transistor base drive current, $\mathrm{A}$

$\mathrm{I}_{\mathrm{CR}} \quad$ reverse collector current, A

$\mathrm{I}_{\mathrm{SAT}} \quad$ transistor saturation current, A

NP number of turns in primary winding

NS number of turns in secondary winding

ODT outside diameter of core box, in.

OPM ohms per $1000 \mathrm{ft}$ at $20^{\circ} \mathrm{C}$

PCUMAX maximum ohmic losses allowed in the secondary or one half of the primary winding, $\mathrm{W}$

PCU1 ohmic losses in primary winding, $W$

PCU2 ohmic losses in secondary winding, $W$

PLOSS total transformer losses, W

! $\mathbf{R}^{\prime}$

relative reluctance of core, $\mathrm{cm}^{-1}$

R1 primary resistance, ohm

R2 secondary resistance, ohm

RDENS density of substitute coil material relative to copper 
REGUL final transformer regulation

RRES resistance of substitute coil material relative to copper

SKND skin depth, $\mathrm{m}$

SURFT total surface area of transformer, $\mathrm{cm}^{2}$

$\mathrm{T}$ transformer operating temperature, ${ }^{\circ} \mathrm{C}$

TAMB ambient temperature, ${ }^{\circ} \mathrm{C}$

TAPEV voltage rating of insulating tape in volts $/ \mathrm{mil}$

TEMCOR temperature coefficient of resistance for substitute material, ${ }^{\circ} \mathrm{C}^{-1}$

$\mathrm{t}_{\mathrm{f}} \quad$ transistor switching fall time, sec

$\mathrm{t}_{\mathrm{r}} \quad$ transistor switching rise time, sec

V1 primary voltage, V

V2 desired secondary voltage, $\mathrm{V}$

V2FL full load output voltage delivered, V

V2O no load output voltage, V

$\mathrm{V}_{\mathrm{BE}} \quad$ transistor base-emitter voltage, $\mathrm{V}$

$\mathrm{V}_{\mathrm{SAT}} \quad$ transistor saturation voltage, $\mathrm{V}$

VAPP specific exciting apparent power, (VA/lb)

WA core box window area, cir. mils

WAC core window area, cross sectional area product, $\mathrm{cm}^{2}$-cir. mils

WACO minimum core window area, cross sectional area product, $\mathrm{cm}^{2} \times$ cir. mils

WATPP specific core loss, watts/lb

W.RAP1 number of parallel primary conductors

WRAP2 number of parallel secondary conductors

XLONG1 length of primary winding, in.

XLONG2 length of secondary winding, in.

$\epsilon$

thermal emissivity, dimensionless

permeability, henrys $/ \mathrm{m}$

magnetic flux, We

electrical conductivity, ohm $/ \mathrm{m}$ 


\section{PREPARATION OF THE DATA}

The user must first decide which set of magnetic core data to use. The two sets, labeled "heavy" and "light," produce transformers of somewhat different characteristics and are discussed in more detail in appendix $A$.

Next, a set of data cards specifying the transformers to be designed must be prepared. These cards are read into the machine on a Namelist format with a class name of "IN." To design a transformer, the computer must be given values for V1, V2, CUR1, F, FF, PCUMAX, BMAX, DENSITY, TAPEV, WATPP, VAPP, TAMB, CU, A, RRES, and CMPA. If a metal other than copper is used in the windings the resistivity relative to copper at $20^{\circ} \mathrm{C}, \mathrm{RRES}$, must be computed and placed in the input statement along with the temperature coefficient of resistivity at $20^{\circ} \mathrm{C}, \mathrm{TEMCOR}$, and the density relative to copper, RDENS. If copper is used RRES must be specified as 1.0 .

The first word of the data statement for each transformer is $\$ I N$ which is begun in column two. After this the rest of the data are written in the form $\mathrm{V} 1=32.0, \mathrm{~V} 2=$ 2000 . 0 , etc. The data need not be in the same order as in the Namelist declaration, and data that are unchanged from the previous data statement need not be repeated. The statement is ended by typing $\$$ after the last data specification. A detailed explanation of the Namelist declaration is presented by Organick (ref. 4).

The program, including core and wire libraries and a sample data input, is included in appendix $\mathrm{B}$.

\section{DESCRIPTION OF THE PROGRAM}

The first step in the computation is to determine the number of parallel conductors WRAP1 and the wire size that will be required to make up the primary coil. The specified inverse current density CMPA is used to determine the wire size and WRAP1 on the first iteration, but, if ohmic losses exceed PCUMAX, current density is reduced and the computation repeated. Since only half of the primary winding is used at one time, CMPA is halved in making this computation.

Next, the wire diameter is compared with the skin depth SKND at the specified

frequency. Skin depth is computed for the winding material at $20^{\circ} \mathrm{C}$ using the relation

$$
\operatorname{SKND}=(\pi \sigma \mathrm{F} \mu)^{-1 / 2}
$$

The wire diameter is held to no more than 1.5 skin depths so that current density in the wire is approximately uniform at the operating frequency (ref. 5). When a smaller diameter wire size must be chosen to compensate for skin depth, the number of parallel 
conductors in the coil is appropriately increased. No provision is made to correct skin depth for temperature rises that occur during transformer operation.

If the DC source feeding the inverter is considered a perfect voltage generator and the inverter transistors can be taken as perfect switches, the primary voltage V1 is alternately applied to each half of the primary winding for one half of a cycle. Thus the primary winding may be represented as a single winding of one half the number of turns and driven by a perfect square wave generator $e_{1}$. The voltage relation at the primary terminals is then

$$
\mathrm{e}_{1}=\frac{\mathrm{NP}}{2} \frac{\mathrm{d} \varphi}{\mathrm{dt}}
$$

During a half cycle of operation this equation may be written

$$
\mathrm{V} 1=2 \mathrm{NP} \times \mathrm{BMAX} \times \mathrm{F} \times \mathrm{AC} \times 10^{-8}
$$

where $\mathrm{AC}$ is the effective core cross sectional area, and BMAX is the maximum magnetic flux density in the core.

The user must specify the approximate fraction FF of the window area of the core that will be filled with the windings. Since the primary and secondary windings will take up about the same cross section, a second equation involving NP may be written:

$$
\mathrm{NP} \times \mathrm{AWT} \times \text { WRAP } 1=\frac{\mathrm{WA} \times \mathrm{FF}}{2}
$$

where AWT, the total wire cross section area, and WA, the window area, must be in the same units.

Combining equations (3) and (4) results in an expression for the window-area, corearea product:

$$
\mathrm{WA} \times \mathrm{AC}=\mathrm{WACO}=\frac{\mathrm{V} 1 \times \mathrm{AWT} \times \mathrm{WRAP} 1 \times 10^{8}}{\mathrm{~F} \times \mathrm{BMAX} \times \mathrm{FF}}
$$

The computer then sorts through the cores in its library, which are arranged in order of increasing WAC, and selects for use in the transformer the first core having a WA-AC product (WAC) greater than WACO. In each library only one core is listed at any value of $W A C$, so that the choice is unambiguous.

The number of primary turns are then computed using equation (3) and appropriately rounded off so that NP is an even whole number. This value of NP is then substi- 
tuted into equation (3) to obtain BUSED, the actual magnetic flux density. BUSED will be approximately equal to BMAX unless NP is very small, say, 2 or 4 . The data on specific apparent power and core loss are subsequently multiplied by the ratio BUSED/ BMAX to approximate linearly the variation in $\mathrm{B}$.

Using NP the fraction of the core window area filled by the primary winding FIL1 is computed:

$$
\text { FIL1 }=\frac{\text { NP } \times \text { WRAP1 } \times \text { AWT }}{\text { WA }}
$$

When a load of unity power factor is assumed and leakage inductance is neglected, the number of turns needed in the secondary NS may be computed. First, the resistance $\mathrm{R} 1$ is computed from the known diameter and composition of the wire, the ambient temperature, and the length of the winding XLONG1, which is estimated as

$$
\begin{gathered}
\text { XLONGI }=\mathrm{NP}[2 \mathrm{HTT}+\mathrm{ODT}+\mathrm{DITC}(1-2 \sqrt{1-\text { FIL1 }})] \\
\mathrm{R} 1=\frac{\mathrm{OPM} \times \mathrm{XLONG} 1(\mathrm{CU}+\mathrm{A} \times \mathrm{RRES})[1.0+(\mathrm{CU} \times 0.00393+\mathrm{A} \times \mathrm{TEMCOR})](\mathrm{TAMB}-20.0)}{24000.0 \times \mathrm{WRAP} 1}
\end{gathered}
$$

After computing the primary resistance, FIL1 is increased to allow for insulating tape between the primary and secondary windings and then checked to be no greater than $0.64 \times \mathrm{FF}$, otherwise the core having the next larger WAC is chosen.

After determining that the primary coil dissipation does not exceed twice PCUMAX, the number of turns needed in the secondary is computed,

$$
\mathrm{NS}=\frac{\mathrm{NP} \times \mathrm{V} 2}{2(\mathrm{~V} 1-2 \mathrm{CURI} \times \mathrm{R} 1)}
$$

and rounded off to the next largest whole number.

The mass of the core CORWAT is computed, and the excitation current CUREX is found:

$$
\text { CUREX }=\frac{\text { VAPP } \times \text { CORWAT } \times \text { BUSED }}{(\text { VI } \times \text { BMAX })}
$$

No provision is made for variations in CUREX or PIRON due to changes in core temperature. As it will be shown later, this simplification is a good one for most of 
the cores treated in this report.

The secondary current CUR2 is computed for a load of unity power factor, neglecting leakage inductance and the phase lag between CUR1 and CUREX.

$$
\text { CUR2 }=\frac{\text { NP } \times(\text { CUR1 }- \text { CUREX })}{2 N S}
$$

The process of choosing a wire size and the number of parallel conductors is then repeated for the secondary coil. The fill factor FIL2 is computed and allowance made for insulating tape between layers. The next larger core is chosen if the sum of FIL1 and FIL2 is greater than 1.28 times FF.

The length of wire in the secondary coil XLONG2 is calculated using the formula

$$
\mathrm{XLONG2}=\mathrm{NS} \times[2 \mathrm{HTT}+\mathrm{ODT}+3 \mathrm{DITC}-2(\mathrm{AD}+\mathrm{BD})]
$$

where

$$
\mathrm{AD}=\mathrm{DITC} \sqrt{1-\text { FIL1 }}
$$

and

$$
\mathrm{BD}=\mathrm{DITC} \sqrt{1-\text { FIL1 }- \text { FIL2 }}
$$

The resistance R2 at ambient temperature and secondary power dissipation PCU2 are then computed.

The outside surface area SURFT of the wound toroid is calculated as if it were a smooth surface:

$$
\text { SURFT }=6.45 \pi\left[(\mathrm{ODT}+\mathrm{DITC}-\mathrm{BD})(\mathrm{HTT}+\mathrm{DITC}-\mathrm{BD})+\frac{1}{2}(\mathrm{ODT}+\mathrm{DITC}-\mathrm{BD})^{2}-\frac{\mathrm{BD}^{2}}{2}\right]
$$

Since the transformer would be operating in the vacuum of space, only radiation is considered as a mechanism for heat transfer. The temperature of operation $T$ is, there- : fore, estimated by the equation

$$
\mathrm{T}=\left[\frac{\mathrm{PCU} 1+\mathrm{PCU} 2+\mathrm{PIRON}}{5.67 \times 10^{-8} \epsilon \text { SURFT }}+(\mathrm{TAMB}+273)^{4}\right]^{1 / 4}-273
$$


where the relative emissivity $\epsilon$ is taken to be 0.95 for most transformer materials (ref. 6):

The temperature calculated from equation (16) must be recognized as an estimate only. The assumption is made that the entire outside surface of the toroid, that is, all but the inside surface of the hole, is free to radiate to a sink of constant temperature TAMB. What fraction of the surface is actually free to radiate depends on the placement of the transformer in the vehicle, and the temperature will rise if the effective radiating surface or emissivity is reduced. Furthermore, this estimate of temperature does not consider temperature gradients within the transformer; this effect will be examined later. On the other hand, equation (16) implies that no provision is made for cooling the transformer by conduction. If the temperature so calculated is considered excessive for the materials being used, then some allowance must be made for cooling the transformer; in this sense equation (16) estimates an upper limit of operating temperature.

Using the estimated operating temperature from equation (16), the program then recomputes all of the resistances and power dissipations and temperature until on successive iterations the total power loss in the transformer has changed by less than 1 percent, which corresponds to a temperature change of less than 0.25 percent.

Having completed the temperature iteration, it is necessary to determine if the desired full-load output voltage V2 will be delivered. For this purpose the full-load output voltage must be estimated using the expression,

$$
\mathrm{V} 2 \mathrm{FL}=\frac{2 \mathrm{NS}(\mathrm{V} 1-\mathrm{CUR} 1 \times \mathrm{R} 1)}{\mathrm{NP}}-\mathrm{CUR} 2 \times \mathrm{R} 2
$$

If $\mathrm{V} 2 \mathrm{FL}$ is less than $\mathrm{V} 2$, a new value of $\mathrm{NS}$ is computed as

$$
\mathrm{NS}=\frac{(\mathrm{V} 2+\mathrm{CUR} 2 \times \mathrm{R} 2) \mathrm{NP}}{2(\mathrm{~V} 1-\mathrm{CUR} 1 \times \mathrm{R} 1)}
$$

The program then corrects CUR2, using the new NS, and recomputes the temperature and secondary voltage until a transformer design with V2FL greater than V2 is achieved.

At this point the program has finished in its design calculations and sets about computing those quantities specified for the output statement. The weight of the windings are calculated using the length, mass per unit length, and number of parallel windings for each coil. The mass of the insulation on the wire is neglected. Efficiency is taken as

$$
\text { EFISH }=100\left[1-\frac{\text { PLOSS }}{\text { V1 } 1 \times \text { CUR } 1}\right]
$$


The final fill factor FILF is simply

$$
\text { FILF }=\text { FIL1 + FIL2 }
$$

The regulation REGUL of the transformer is defined as the percent voltage drop from no load to full load of unity power factor, neglecting leakage inductance and the phase lag of excitation current:

$$
\mathrm{REGUL}=100 \frac{(\mathrm{V} 20-\mathrm{V} 2 \mathrm{FL})}{\mathrm{V} 2 \mathrm{FL}} \%
$$

where V20, the no-load output voltage is given by

$$
\mathrm{V} 20=2 \mathrm{NS} \frac{(\mathrm{V} 1-\mathrm{CUREX} \times \mathrm{R} 1)}{\mathrm{NP}}
$$

The outer diameter FOD and the height FHTT of the wound toroid are calculated:

$$
\begin{gathered}
\text { FOD }=2.54(\mathrm{ODT}+\mathrm{DITC}-\mathrm{BD}) \\
\mathrm{FHTT}=2.54(\mathrm{HTT}+\mathrm{DITC}-\mathrm{BD})
\end{gathered}
$$

For this application it was of interest to vary some of the input quantities over a wide range to determine the changes of some transformer parameters. To assist in this work, a computer program was written to plot curves of some of these results. Owing to individual differences in curve plotting equipment, this part of the program was considered to be of less general interest and is not discussed here, but may be obtained from the author.

\section{TRANSFORMER DESIGN}

The computer program was applied to the design of transformers for inverters of $2.0(125 \mathrm{~A}, 16 \mathrm{~V} / 2000 \mathrm{~V})$ and 4.0 kilovolt-amperes $(125 \mathrm{~A}, 32 \mathrm{~V} / 2000 \mathrm{~V})$ capacity. A presentation of the results of this design will serve to illustrate the use of the program.

When the ohmic power consumption restriction is removed by making PCUMAX a large fraction of the output power, the transformer design will be determined primarily by the materials used, the frequency, and the inverse current density in the windings, which permits an examination of the effect of these parameters on the transformer oper- 
TABLE I. - EFFECT OF CURRENT

[2 kVA $(16 / 2000 \mathrm{~V})$; frequency, $800 \mathrm{~Hz}$; ambient

\begin{tabular}{|c|c|c|c|c|c|c|c|c|c|c|c|c|}
\hline \multirow{2}{*}{$\begin{array}{c}\text { Type of } \\
\text { core }\end{array}$} & \multirow{2}{*}{$\begin{array}{l}\text { Inverse } \\
\text { current } \\
\text { density. } \\
\text { CMPA }\end{array}$} & \multicolumn{8}{|c|}{ Primary coil characteristics } & \multicolumn{3}{|c|}{ Secondary coil } \\
\hline & & $\begin{array}{l}\text { Current } \\
\text { delivered } \\
\text { by trans- } \\
\text { former } \\
\text { to load, } \\
\text { CuR2, } \\
\text { A }\end{array}$ & $\begin{array}{c}\text { Excita- } \\
\text { tion } \\
\text { current, } \\
\text { CUREX, } \\
\text { A }\end{array}$ & $\begin{array}{c}\text { Number } \\
\text { of turns. } \\
\text { NP }\end{array}$ & $\begin{array}{c}\text { Wire } \\
\text { gauge, } \\
\text { IAWGI }\end{array}$ & $\begin{array}{l}\text { Number of } \\
\text { parallel } \\
\text { windings, } \\
\text { WRAP1 }\end{array}$ & \begin{tabular}{|c|} 
Resist- \\
ance, \\
$\mathrm{R} 1$ \\
$\mathrm{~m} \Omega$
\end{tabular} & $\begin{array}{c}\text { Ohmic } \\
\text { losses. } \\
\text { PCU1, } \\
W\end{array}$ & $\begin{array}{l}\text { Mass of } \\
\text { primary } \\
\text { coil. } \\
\text { CUWAT } 1 \text {. } \\
\text { kg }\end{array}$ & $\begin{array}{c}\text { Number } \\
\text { of turns. } \\
\text { NS }\end{array}$ & $\begin{array}{c}\text { Wire } \\
\text { gauge, } \\
\text { IAWG2 }\end{array}$ & $\begin{array}{c}\text { Number of } \\
\text { parallel } \\
\text { windings, } \\
\text { WRAP2 }\end{array}$ \\
\hline \multirow[t]{11}{*}{ Heavy } & 3125 & 0.948 & 6.16 & 10 & 8 & 12 & 0.228 & 3.6 & 1.352 & 627 & 15 & 1 \\
\hline & 2500 & .946 & 6.16 & 10 & & 10 & .272 & 4.2 & 1.099 & 628 & 16 & \\
\hline & 2000 & .946 & 6.16 & 10 & & 8 & .338 & 5.3 & .858 & 628 & 17 & \\
\hline & 1600 & .947 & 5.90 & 8 & . & 6 & .416 & .6 .5 & .575 & 503 & 18 & \\
\hline & 1270 & .956 & 4.52 & 10 & $\varphi$ & 5 & .537 & 8.4 & .526 & 630 & 19 & 1 \\
\hline & 1000 & .955 & 4.52 & 10 & 8 & 4 & .673 & 10.5 & .413 & 631 & 20 & 1 \\
\hline & 800 & .965 & 2.70 & 16 & 8 & 3 & 1.09 & 17.1 & .381 & 1014 & 21 & \\
\hline & 640 & .961 & 2.64 & 14 & 9 & 3 & 1. 47 & 22.9 & .307 & 891 & 22 & \\
\hline & 512 & .959 & 2.44 & 16 & 8 & 2 & 1.71 & 26.7 & .247 & 1022 & 23 & \\
\hline & 410 & .931 & 1.17 & 42 & 9 & 2 & 4. 58 & 71.6 & .384 & 2794 & 24 & \\
\hline & 328 & .942 & 1.64 & 20 & 10 & 2 & 3.59 & 56.1 & .181 & 1309 & 25 & 1 \\
\hline \multirow[t]{11}{*}{ Light } & 3125 & 0.954 & 5.30 & 12 & 8 & 12 & 0.260 & 4. 1 & 1. 578 & 753 & 15 & 1 \\
\hline & 2500 & .954 & 5.30 & 12 & & 10 & .309 & 4.8 & 1.278 & 753 & 16 & \\
\hline & 2000 & .962 & 4.11 & 14 & & 8 & .425 & 6.6 & 1. 136 & 880 & 17 & \\
\hline & 1600 & .959 & 4.28 & 12 & & 6 & .509 & 7.9 & .741 & $755^{\circ}$ & 18 & \\
\hline & 1270 & .967 & 2.88 & 20 & 1 & 5 & .773 & $12: 1$ & .800 & 1263 & 19 & 1 \\
\hline & 1000 & .965 & 2.88 & 20 & 8 & 4 & .962 & 15.0 & .618 & 1266 & 20 & 1 \\
\hline & 800 & .964 & 2.46 & & 8 & 3 & 1.30 & 20.3. & .454 & 1271 & 21 & \\
\hline & 640 & .963 & 2.05 & & 9 & 3 & 1.68 & 26.2 & .355 & 1277 & 22 & \\
\hline & 512 & .958 & 2.05 & 1 & 8 & 2 & 2.04 & 31.8 & .292 & 1283 & 23 & \\
\hline & 410 & .890 & .770 & 72 & 9 & 2 & 7.51 & 117.3 & .600 & 5026 & 24 & \\
\hline & 328 & .892 & .875 & 54 & 10 & 2 & 7.63 & 119.3 & .361 & 3759 & 25 & \\
\hline
\end{tabular}




\section{DENSITY ON TRANSFORMER DESIGN}

temperature, $127^{\circ} \mathrm{C}$; copper windings; Supermendur core.]

\begin{tabular}{|c|c|c|c|c|c|c|c|c|c|c|c|c|c|}
\hline \multicolumn{3}{|c|}{ characteristics } & \multicolumn{3}{|c|}{ Core characteristics } & \multicolumn{8}{|c|}{ Overall transformer characteristics } \\
\hline $\begin{array}{c}\text { Resist- } \\
\text { ance, } \\
\text { R2, } \\
\Omega\end{array}$ & $\begin{array}{c}\text { Olmic } \\
\text { losses. } \\
\text { PCU2, } \\
\text { W }\end{array}$ & $\begin{array}{c}\text { Mass of } \\
\text { secondary } \\
\text { coil, } \\
\text { CUWAT2, } \\
\text { kgr }\end{array}$ & $\begin{array}{c}\text { Serial } \\
\text { number } \\
\text { ICORNO }\end{array}$ & $\begin{array}{c}\text { Mass of } \\
\text { core iron, } \\
\text { CORWAT, } \\
\mathrm{kg}\end{array}$ & $\begin{array}{c}\text { Core } \\
\text { loss, } \\
\text { W }\end{array}$ & $\begin{array}{c}\text { Final regu- } \\
\text { lation, } \\
\text { REGUL, } \\
\text { percent }\end{array}$ & $\begin{array}{c}\text { Total } \\
\text { losses, } \\
\text { PLOSS, } \\
\text { W }\end{array}$ & $\begin{array}{c}\text { Effi- } \\
\text { ciency, } \\
\text { EFISH, } \\
\text { percent }\end{array}$ & $\begin{array}{c}\text { Total } \\
\text { weight, } \\
\text { TOTWAT, } \\
\text { kgm }\end{array}$ & $\begin{array}{l}\text { Final } \\
\text { fill } \\
\text { factor, } \\
\text { FILF }\end{array}$ & $\begin{array}{c}\text { Temper- } \\
\text { ature, } \\
\mathrm{T}, \\
{ }^{\circ} \mathrm{C}\end{array}$ & $\begin{array}{c}\text { Full-load } \\
\text { output } \\
\text { voltage } \\
\text { delivered, } \\
\text { V2FL, }\end{array}$ & $\begin{array}{c}\text { Actual } \\
\text { magnetic- } \\
\text { flux } \\
\text { density, } \\
T\end{array}$ \\
\hline 2.30 & 2.1 & 1.847 & 237 & 1. 773 & 86.3 & 0.278 & 91.9 & 95.41 & 4.973 & 0.563 & 210.9 & 2000.7 & 1. 62 \\
\hline 2.75 & 2.5 & 1.359 & 237 & 1.773 & 86.3 & .333 & 93.0 & 95.35 & 4.231 & .460 & 219.7 & 2002.7 & 1. 62 \\
\hline 3.29 & 2.9 & 1.009 & 237 & 1.773 & 86.3 & .408 & 94.5 & 95.28 & 3.640 & .368 & 228.6 & 2001.2 & 1.62 \\
\hline 3.71 & 3.3 & .689 & 235 & 1.510 & 82.7 & .486 & 92.5 & 95.38 & 2.774 & .426 & 243.8 & 2002.0 & 1. 82 \\
\hline 5.21 & 4.8 & .622 & 234 & 1.300 & 63.3 & .656 & 76.4 & 96.18 & 2.449 & .513 & 234.0 & 2002.6 & 1.62 \\
\hline 6.34 & 5.8 & .469 & 234 & 1.300 & 63.3 & .814 & 79.6 & 96.02 & 2.182 & .412 & 244.6 & 2002.5 & 1.62 \\
\hline 10.8 & 10.0 & .503 & 232 & .690 & 37.7 & 1.37 & 64.8 & 96.76 & 1.574 & .513 & 239.8 & 2000.3 & 1.82 \\
\hline 13.6 & 12.5 & .378 & 231 & .709 & 37.0 & 1. 80 & 72.5 & 96.38 & 1.394 & .477 & 262.2 & 2000.2 & 1.73 \\
\hline 17.0 & 15.6 & .295 & 230 & .624 & 34.1 & 2.15 & 76.5 & 96.18 & 1.166 & .449 & 273.2 & 2000.4 & 1. 82 \\
\hline 56.5 & 48.9 & .562 & 228 & .315 & 16.4 & 6.40 & 136.9 & 93.15 & 1.261 & .475 & 316.2 & 2000.0 & 1.74 \\
\hline 37.0 & 32.9 & .222 & 227 & .420 & 23.0 & 4.64 & 111.9 & 94.40 & .823 & .505 & 341.6 & 2000.8 & 1.82 \\
\hline 2.71 & 2.5 & 2.230 & 138 & 1.527 & 74.3 & 0.324 & 80.8 & 95.96 & 5.335 & 0.570 & 200.6 & 2001.3 & 1.62 \\
\hline 3.22 & 2.9 & 1.624 & 138 & 1.527 & 74.3 & .386 & 82.0 & 95.90 & 4. 429 & .466 & 209.7 & 2000.0 & 1. 62 \\
\hline 4. 56 & 4.2 & 1.468 & 137 & 1.103 & 57.5 & .542 & 68.4 & 96.58 & 3.708 & .516 & 205.7 & 2000.4 & 1.74 \\
\hline 4. 92 & 4.5 & .963 & 136 & 1.231 & 59.9 & .622 & 72.4 & 96.38 & 2.936 & .508 & 219.0 & 2000.6 & 1. 62 \\
\hline 8.56 & 8.0 & 1.078 & 135 & .736 & 40.3 & 1.01 & 60.3 & 96.98 & 2.613 & .468 & 209.5 & 2000.3 & 1.82 \\
\hline 10.1 & 9.4 & .786 & 135 & .736 & 40.3 & 1. 23 & 64.7 & 96.76 & 2.139 & .376 & 222.9 & 2000.6 & 1. 82 \\
\hline 13.0 & 12.1 & .613 & 134 & .630 & 34.5 & 1.64 & 66.9 & 96.66 & 1.698 & .433 & 237.1 & 2000.4 & 1.82 \\
\hline 16.9 & 15.7 & .477 & 133 & .525 & 28.8 & 2.13 & 70.6 & 96.47 & 1.357 & .514 & 256.1 & 2000.1 & $1.82^{\circ}$ \\
\hline 20.8 & 19. 1 & .359 & 133 & $: 525$ & 28.8 & 2.60 & 79.7 & 96.02 & 1. 177 & .424 & 277.0 & 2000.2 & 1.82 \\
\hline 114.1 & 90.3 & 1.083 & 131 & .199 & 10.8 & 11.6 & 218.4 & 89.08 & 1. 882 & .550 & 342.8 & 2001.3 & 1.80 \\
\hline 104.5 & 83.1 & .588 & 130 & .227 & 12.2 & 11.2 & 214.6 & 89.27 & 1. 176 & .516 & 379.5 & 2001.6 & 1.80 \\
\hline
\end{tabular}




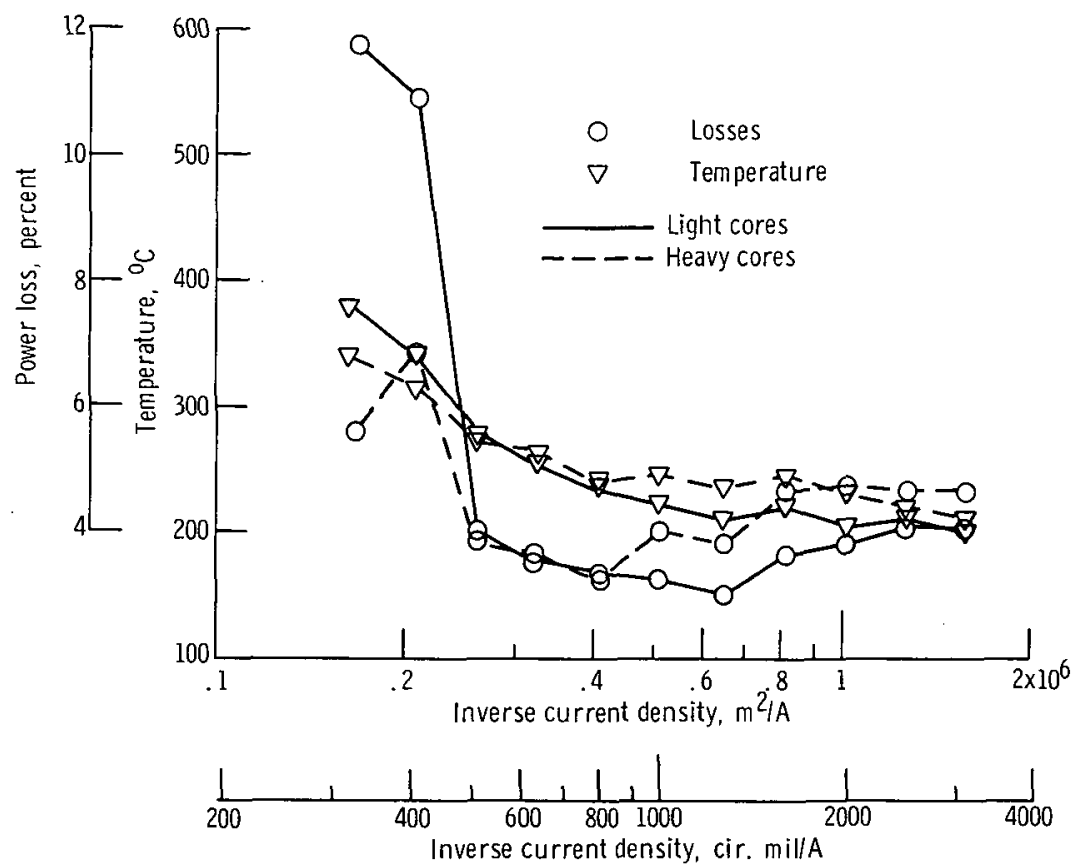

Figure 2. - Variation of power loss and temperature with changes in current density. Copper coils; Supermendur core; frequency, 800 hertz; volt-amperage, 2 kilovoltamperes $(16 / 2000 \mathrm{~V})$; ambient tem perature, $127^{\circ} \mathrm{C}$; fill factor, 0.5 .

ating conditions. A typical variation of power loss and temperature in a 2.0-kilovoltampere transformer at 800 hertz and at an ambient temperature of $127^{\circ} \mathrm{C}$ with variations in the inverse current density is presented in figure 2. Data on specific core loss in this computation were obtained from Frost, McVay, and Pavlovic (ref. 7) for a 2-mil Supermendur (ref. 8) tape at $250^{\circ} \mathrm{C}$ and 1.8 tesla, excited by a square wave of current. The effect of adding insulating tape is not included. Much greater detail of the transformer designs in the center portion of figure 2 is presented in table I. At low current densities (high CMPA), where ohmic losses are less important, the transformers wound on the heavy cores have greater losses and run hotter than those on light cores. However, as current density increases, the copper losses increase rapidly in the higherresistance coils needed to drive the higher-reluctance, light magnetic cores causing them to operate at a higher temperature and lower efficiency.

It should be particularly noted in figure 2 that the transformer designs reach broad minima in losses, indicating that by varying the current density in the windings a most efficient design can be found for given frequency, power input, materials, and heavy or light core. At a given frequency the highest efficiency design is generally not achieved at the same current density for light and heavy cores. A comparison of the weight, power loss, and operating temperature of the most efficient 2-kilovolt-ampere transformers wound on light and heavy cores is given in figure 3 as a function of frequency. The light-core transformers are more efficient in all but one case and operate at lower 


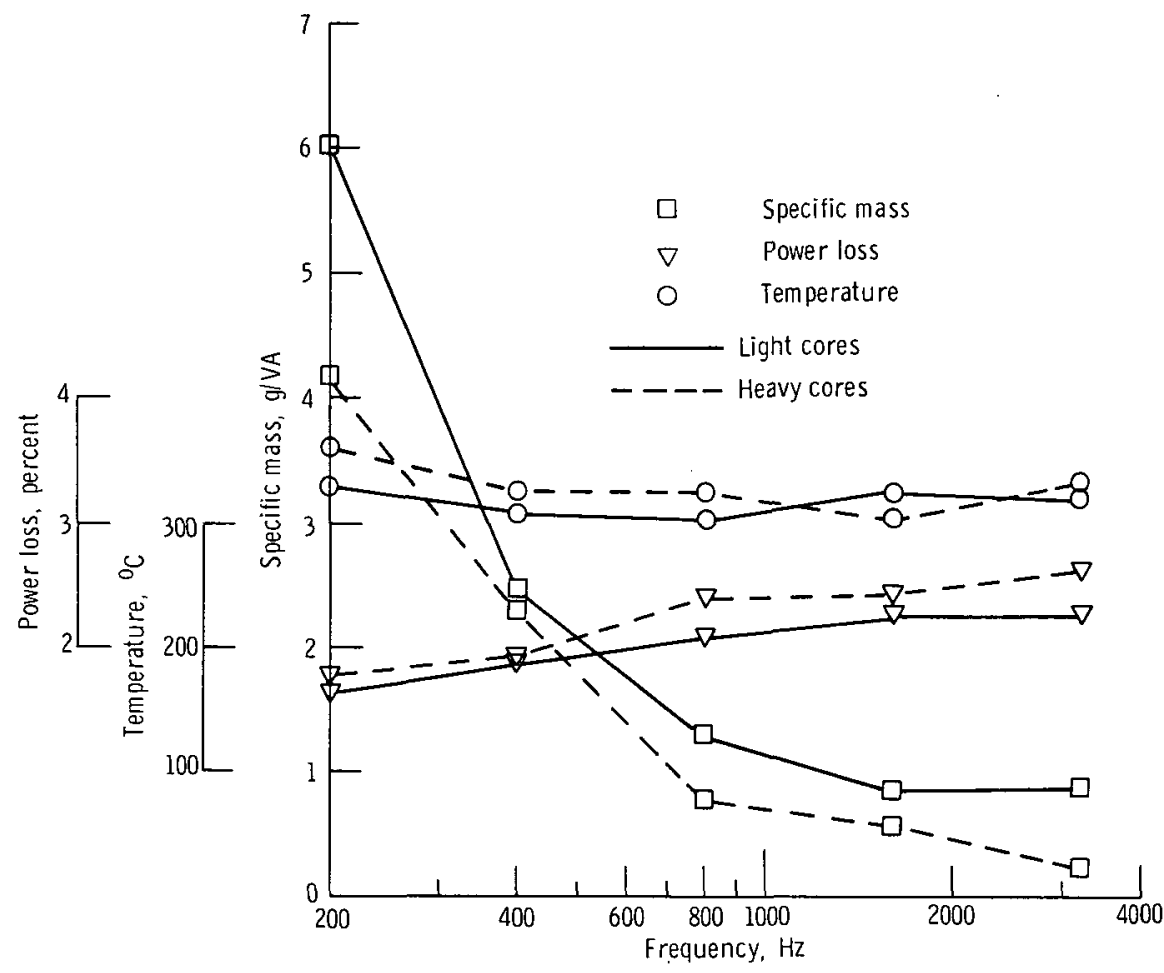

Figure 3. - Properties of the most efficient transformer designs. Copper coils; Supermendur core; volt-amperage, 2 kilovolt-amperes $(16 / 2000 \mathrm{~V})$; ambient temperature, $127^{\circ} \mathrm{C}$; fill factor, 0.5.

temperatures than do the low-gain core transformers, but they weigh more than 50 percent as much at some frequencies. In the one case at 1600 hertz where the heavy core transformer is more efficient, core 228, chosen by the program, is one that is on the borderline between heavy and light cores, having a diameter ratio of 0.714 . The interrelation of efficiency, weight, and temperature as a function of frequency is evident in figure 3. The total power loss for these most efficient designs varies relatively little, but temperature rises and weight falls for increasing frequency. Efficiency varies between 96.71 and 96.98 percent for the highest efficiency transformers.

For transformers wound on heavy and light cores with aluminum wire, the light cores produce transformers somewhat more efficient and heavier than the heavy core. However, the differential in weight is not as great as when copper wire is used.

The most efficient transformer is not necessarily the optimum design for every application as illustrated in figure 4 where the most efficient transformers are compared with the "next best, " usually a transformer one or more steps lower in inverse current density and sometimes wound on a heavy, rather than a light core. At a penalty of a few tenths of a percent in efficiency, a reduction of 50 percent or more in weight can be achieved by using the next best, an important consideration in space and aeronautical applications. Table II contains a detailed description of the most efficient and next best 
TABLE II. - COPPER-WOUND

\begin{tabular}{|c|c|c|c|c|c|c|c|c|c|c|c|c|c|c|}
\hline \multirow{2}{*}{$\begin{array}{c}\text { Transformer, } \\
\text { kVA }\end{array}$} & \multirow[t]{2}{*}{ Rating } & \multirow{2}{*}{$\begin{array}{c}\text { Fre- } \\
\text { quency, } \\
\mathrm{Hz}\end{array}$} & \multirow{2}{*}{$\begin{array}{c}\text { Inverse } \\
\text { current } \\
\text { density, } \\
\text { CMPA }\end{array}$} & \multicolumn{8}{|c|}{ Primary coil characteristics } & \multicolumn{3}{|c|}{ Secondary coil } \\
\hline & & & & $\begin{array}{c}\text { Current } \\
\text { delivered } \\
\text { by trans- } \\
\text { former to } \\
\text { load, } \\
\text { CUR2, } \\
\text { A }\end{array}$ & $\begin{array}{c}\text { Excita- } \\
\text { tion } \\
\text { current, } \\
\text { CuREX, } \\
\text { A }\end{array}$ & $\begin{array}{c}\text { Number of } \\
\text { turns, } \\
\text { NP }\end{array}$ & $\begin{array}{c}\text { wire } \\
\text { gauge, } \\
\text { LAWGl }\end{array}$ & $\begin{array}{l}\text { Number of } \\
\text { parallel } \\
\text { windings, } \\
\text { WRAPl }\end{array}$ & $\begin{array}{c}\text { Resist- } \\
\text { ance, } \\
\mathrm{R} 1 \\
\mathrm{~m} \Omega\end{array}$ & $\begin{array}{l}\text { Ohmic } \\
\text { losses, } \\
\text { PCU1, } \\
\text { W }\end{array}$ & $\begin{array}{c}\text { Mass of } \\
\text { primary } \\
\text { coil, } \\
\text { CUWAT1, } \\
\text { kg }\end{array}$ & $\begin{array}{c}\text { Number of } \\
\text { turns, } \\
\text { NS }\end{array}$ & $\begin{array}{c}\text { Wire } \\
\text { gauge, } \\
\text { IAWG2 }\end{array}$ & $\begin{array}{c}\text { Number of } \\
\text { parallel } \\
\text { windings, } \\
\text { WRAP2 }\end{array}$ \\
\hline \multirow[t]{10}{*}{$2^{a}$} & Most & 200 & $\mathrm{~d}_{2500 \mathrm{~L}}$ & 0.963 & 3.23 & 28 & 3 & 3 & 0.838 & 13.1 & 3.519 & 1771 & 16 & 1 \\
\hline & efficient & 400 & $1600 \mathrm{~L}$ & .965 & 2.85 & 22 & 5 & 3 & .909 & 14.2 & 1.427 & 1392 & 18 & 1 \\
\hline & & 800 & $1270 \mathrm{~L}$ & .967 & 2.88 & 20 & 8 & 5 & .773 & 12.1 & .800 & 1263 & 19 & \\
\hline & & 1600 & $800 \mathrm{H}$ & .965 & 2.73 & 20 & 11 & 6 & .985 & 15.4 & .339 & 1267 & 21 & \\
\hline & & 3200 & $1600 \mathrm{~L}$ & .964 & 3.80 & 18 & 14 & 25 & .385 & 6.0 & .592 & 1132 & 18 & $f$ \\
\hline & Next & 200 & $1270 \mathrm{H}$ & 0.957 & 3.29 & 20 & 4 & 2 & 1. 282 & 20.0 & 1. 409 & 1272 & 19 & 1 \\
\hline & best & 400 & $1000 \mathrm{~L}$ & .962 & 2.02 & 28 & 5 & 2 & 1.701 & 26.6 & 1. 137 & 1790 & 20 & 1 \\
\hline & & 800 & $800 \mathrm{H}$ & .965 & 2.70 & 16 & 8 & 3 & 1. 094 & 17.1 & .381 & 1014 & 21 & \\
\hline & & 1600 & $512 \mathrm{H}$ & .963 & 2.44 & 14 & 11 & 4 & 1.354 & 21.2 & .188 & 891 & 23 & \\
\hline & & 3200 & $512 \mathrm{H}$ & .964 & 2.89 & 14 & 14 & 8 & 1.014 & 15.8 & .134 & 887 & 23 & 1 \\
\hline \multirow[t]{10}{*}{$4^{b}$} & Most & 200 & $\mathrm{~d}_{2000 \mathrm{H}}$ & 1.93 & 2.79 & 34 & 2 & 2 & 1.54 & 24.0 & 4.387 & 1074 & 14 & 1 \\
\hline & efficient & 400 & $1600 \mathrm{~L}$ & 1.94 & 2.20 & 34 & 5 & 3 & 1.76 & 27.5 & 2.704 & 1075 & 15 & 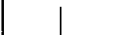 \\
\hline & & 800 & $1000 \mathrm{~L}$ & 1.94 & 2.05 & 28 & 8 & 4 & 1.81 & 28.3 & 1. 136 & 886 & 17 & \\
\hline & & 1600 & $1270 \mathrm{~L}$ & 1.94 & 3.18 & 20 & 11 & 10 & .850 & 13.3 & .799 & 629 & 16 & \\
\hline & & 3200 & $640 \mathrm{~L}$ & 1.94 & 2.08 & 28 & 14 & 10 & 1.75 & 27.4 & .375 & 886 & 19 & $\varphi$ \\
\hline & Next & 200 & $1270 \mathrm{H}$ & 1.93 & 1.96 & 42 & 4 & 2 & 2. 89 & 45.1 & 3.129 & 1338 & 16 & 1 \\
\hline & best & 400 & $1000 \mathrm{H}$ & 1.94 & 2.09 & 32 & 5 & 2 & 2.33 & 36.4 & 1.515 & 1016 & 17 & \\
\hline & & 800 & $800 \mathrm{~L}$ & 1.94 & 2.33 & 22 & 8 & 3 & 2.01 & 31.4 & .673 & 697 & 18 & \\
\hline & & 1600 & $512 \mathrm{~L}$ & 1.94 & 2.27 & 20 & 11 & 4 & 2.20 & 34.4 & .292 & 634 & 20 & \\
\hline & & 3200 & $512 \mathrm{H}$ & 1.93 & 2.89 & 14 & 14 & 8 & 1.53 & 23.9 & .186 & 442 & 20 & \\
\hline
\end{tabular}

$a_{16 / 2000 \mathrm{~V}}$.

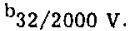

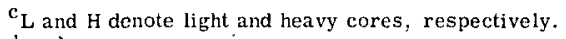

Not a maximum of efficiency. 


\section{TRANSFORMERS}

\begin{tabular}{|c|c|c|c|c|c|c|c|c|c|c|c|c|c|}
\hline \multicolumn{3}{|c|}{ characteristics } & \multicolumn{3}{|c|}{ Core characteristics } & \multicolumn{8}{|c|}{ Overall transformer characteristics } \\
\hline $\begin{array}{c}\text { Resist- } \\
\text { ance, } \\
\mathrm{R} 2 \\
\Omega\end{array}$ & $\begin{array}{c}\text { Olmic } \\
\text { losses, } \\
\text { PCU2, } \\
\text { w }\end{array}$ & $\begin{array}{c}\text { Mass of } \\
\text { secondary } \\
\text { coil. } \\
\text { CUWAT2, } \\
\text { kg }\end{array}$ & $\begin{array}{c}\text { Serial } \\
\text { number, } \\
\text { ICORNO }\end{array}$ & $\begin{array}{c}\text { Niass of } \\
\text { core iron, } \\
\text { CORWAT, } \\
\text { kg }\end{array}$ & $\begin{array}{c}\text { Core } \\
\text { loss, } \\
\text { W }\end{array}$ & $\begin{array}{c}\text { Final regu- } \\
\text { lation, } \\
\text { REGUL, } \\
\text { percent }\end{array}$ & $\begin{array}{c}\text { Total } \\
\text { losses, } \\
\text { PLOSS, } \\
\text { W }\end{array}$ & $\begin{array}{l}\text { Effi- } \\
\text { ciency, } \\
\text { EFISH. } \\
\text { percent }\end{array}$ & $\begin{array}{c}\text { Total } \\
\text { weight, } \\
\text { TOTWAT, } \\
\mathrm{kg}\end{array}$ & $\begin{array}{c}\text { Final } \\
\text { fill } \\
\text { factor, } \\
\text { FILF }\end{array}$ & $\begin{array}{c}\text { Temper- } \\
\text { ature, } \\
\mathrm{T} \\
{ }^{\circ} \mathrm{C}\end{array}$ & $\begin{array}{c}\text { Full-load } \\
\text { output } \\
\text { voltage } \\
\text { delivered, } \\
\text { V2FL, } \\
\text { V }\end{array}$ & $\begin{array}{c}\text { Actual } \\
\text { magnetic- } \\
\text { flux } \\
\text { density, } \\
T\end{array}$ \\
\hline 9. 05 & 8.4 & 5.07 & 145 & 3.468 & 44.3 & 1.08 & 65.7 & 96.71 & 12. 058 & 0.535 & 165.5 & 2002.0 & 1. 74 \\
\hline 9.44 & 8.8 & 1.982 & 138 & 1.527 & 38.7 & 1.16 & 61.7 & 96.92 & 4.94 & .530 & 188.6 & 2001.2 & 1.77 \\
\hline 8.56 & 8. 0 & 1.078 & 135 & .736 & 40.3 & 1.01 & 60.3 & 96.98 & 2.613 & .468 & 209.5 & 2000.3 & 1.82 \\
\hline 10.5 & 9.8 & .487 & 228 & .315 & 35.2 & 1.27 & 60.4 & 96.98 & 1. 14 & .421 & 243.0 & 2001.5 & 1. 82 \\
\hline 4.94 & 4. 6 & .949 & 131 & .199 & 53.3 & .53 & 63.9 & 96.81 & 1. 74 & .506 & 228.0 & 2001.6 & 1.80 \\
\hline 12.76 & 11.7 & 1.672 & 241 & 3.362 & 45.1 & 1.60 & 76.8 & 96.16 & 6. 444 & 0.468 & 192.2 & 2002.6 & 1.82 \\
\hline 18.69 & 17.3 & 1.498 & 137 & 1. 103 & 27.5 & 2.24 & 71.3 & 96.43 & 3.74 & .527 & 207.3 & 2000.6 & 1.74 \\
\hline 10.76 & 10.0 & .503 & 232 & .690 & 37.7 & 1.37 & 64.8 & 96.76 & 1.574 & .513 & 239.8 & 2000.3 & 1.82 \\
\hline 13.95 & 12.9 & .234 & 224 & .296 & 31.4 & 1.73 & 65.5 & 96.72 & $.718^{\circ}$ & .548 & 290.8 & 2001.6 & 1.74 \\
\hline 10.94 & 10.2 & .176 & 219 & .158 & 40.6 & 1.31 & 66.6 & 96.67 & .468 & .468 & 313.6 & 2000.8 & 1. 74 \\
\hline 4.12 & 15.4 & 5.625 & 245 & 6. 042 & 76.2 & 0. 99 & 115.6 & 97.11 & 16. 054 & 0.525 & 181.3 & 2001.5 & 1.72 \\
\hline 4.53 & 17.1 & 3.752 & 143 & 2.430 & 59.8 & 1. 12 & 104.3 & 97.39 & 8.885 & .520 & 197.7 & 2000.8 & 1.72 \\
\hline 4.89 & 18.5 & 1. 480 & 137 & 1. 103 & 57.5 & 1. 18 & 104.3 & 97.39 & 3.719 & .518 & 234.8 & 2001.3 & 1.74 \\
\hline 2.32 & 8.7 & 1.073 & 135 & .736 & 82.2 & .55 & 104.1 & 97.40 & 2.607 & .463 & 250.9 & 2001.6 & 1.82 \\
\hline 5.25 & 19.8 & .554 & 130 & .227 & 58.3 & 1. 19 & 105.5 & 97.36 & 1. 156 & .497 & 295.7 & 2001.0 & 1.74 \\
\hline 7.78 & 29.0 & 4.028 & 243 & 4. 20 & 53.6 & 1. 88 & 127.8 & 96.81 & 11.360 & 0.528 & 198.5 & 2000.8 & 1.74 \\
\hline 6.15 & 23.0 & 1.919 & 239 & 2.276 & 56.6 & 1.50 & 116.1 & 97.10 & 5. 709 & .497 & 220.0 & 2001.6 & 1.74 \\
\hline 4.81 & 18.0 & .865 & 136 & 1.231 & 65.3 & 1.24 & 114.8 & 97.13 & 2. 769 & .468 & 259.2 & 2002.4 & 1.77 \\
\hline 5.50 & 20.6 & .354 & 133 & .525 & 58.7 & 1. 39 & 113.7 & 97,16 & 1.171 & .416 & 316.5 & 2000.7 & 1.82 \\
\hline 3.80 & 14.2 & .225 & 225 & .315 & 81.1 & .96 & 119.3 & 97.02 & .727 & .458 & 363.0 & 2001.1 & 1.74 \\
\hline
\end{tabular}




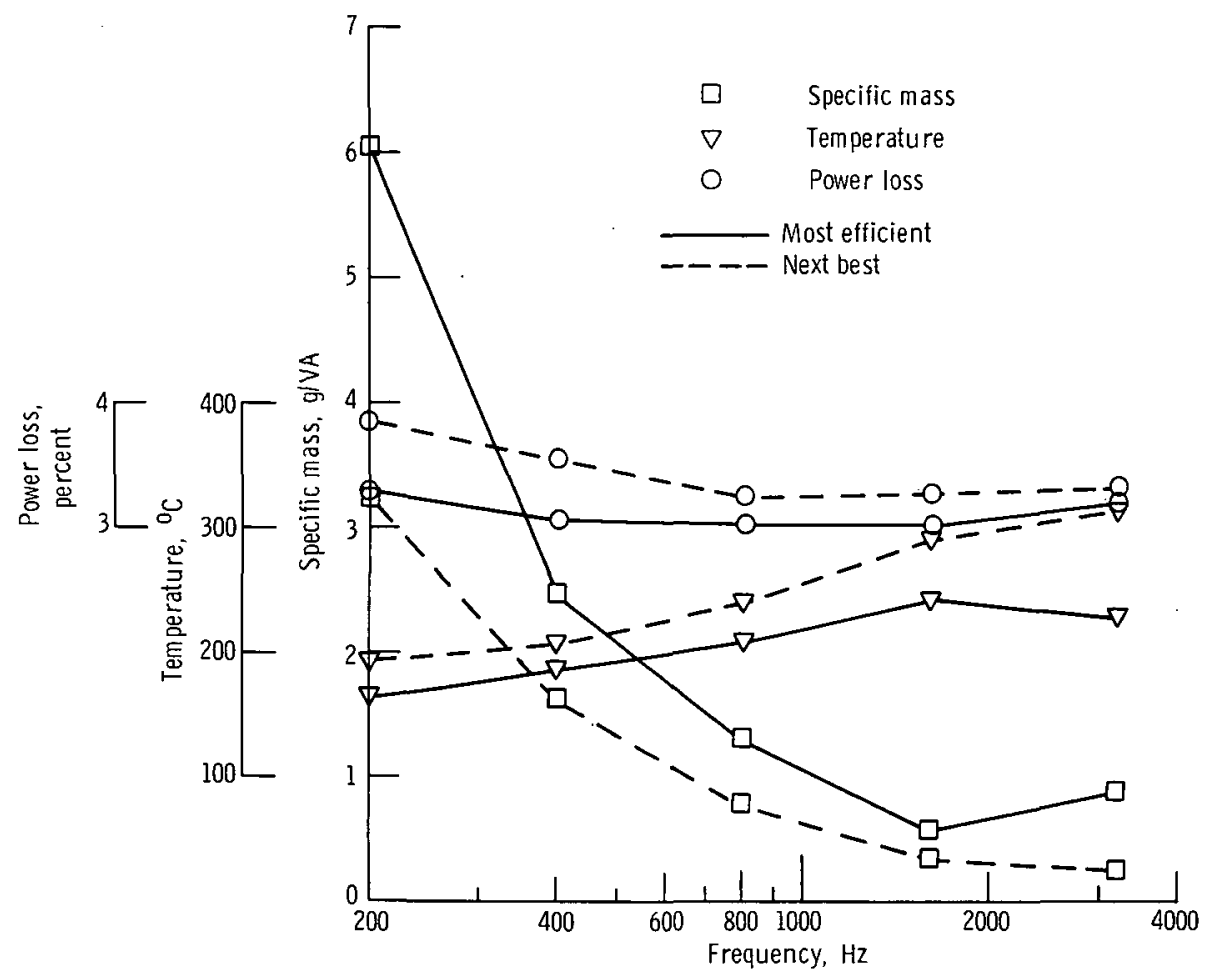

Figure 4. - Comparison of most efficient with next best copper-wound 2-kilovolt-ampere (16) 2000 V) transformer designs. Supermendur core; ambient tem perature, $127^{\circ} \mathrm{C}$; fill factor, 0.5 .

designs at 2 and 4 kilovolt-amperes for transformers wound with copper wire.

In general, a greater reduction in weight, but at the penalty of a correspondingly greater reduction in efficiency, can be achieved by winding the transformer with aluminum rather than copper wire. Figure 5 compares the most efficient copper wound designs with the most efficient aluminum wound transformers. A reduction in efficiency of about a half percent and a reduction in weight of 50 percent result from the substitution of aluminum, but operating temperature is virtually the same.

Similar comparisons of most efficient to next best and of most efficient copper to most efficient aluminum are made for a 4-kilovolt-ampere system in figures 6 and 7 , respectively.

There is no provision in the program for the correction of core loss and excitation current due to changes in the core temperature. The data used in this computation indicate negligible changes for the temperature range from $25^{\circ}$ to $250^{\circ} \mathrm{C}$, which covers 75 percent of the cases in table II. 


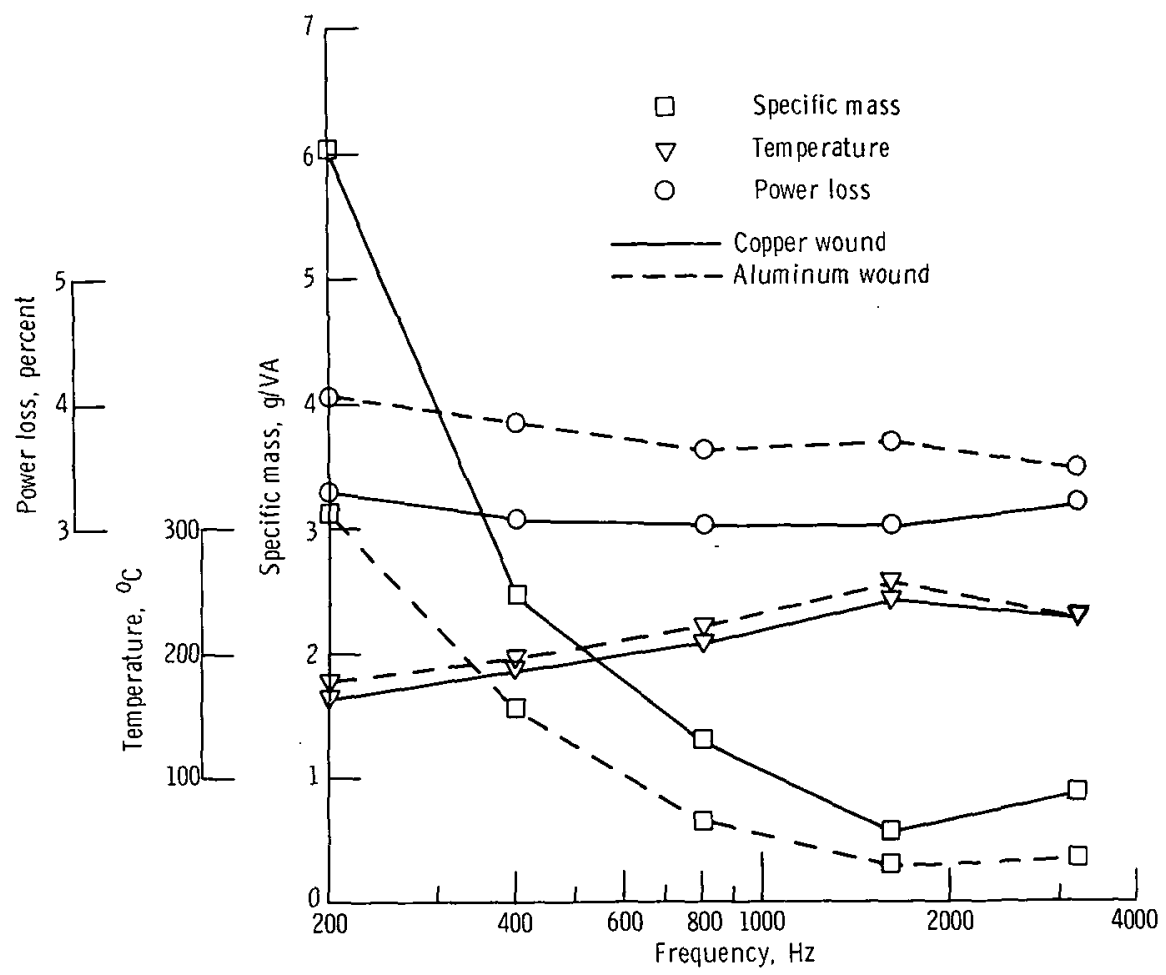

Figure 5. - Comparison of most efficient copper-and aluminum-wound 2-kilovolt-amipe re (16) 2000 Vi transformers. Supermendur cores; ambient temperature, $127^{0} \mathrm{C}$; fill factor, 0.5 .

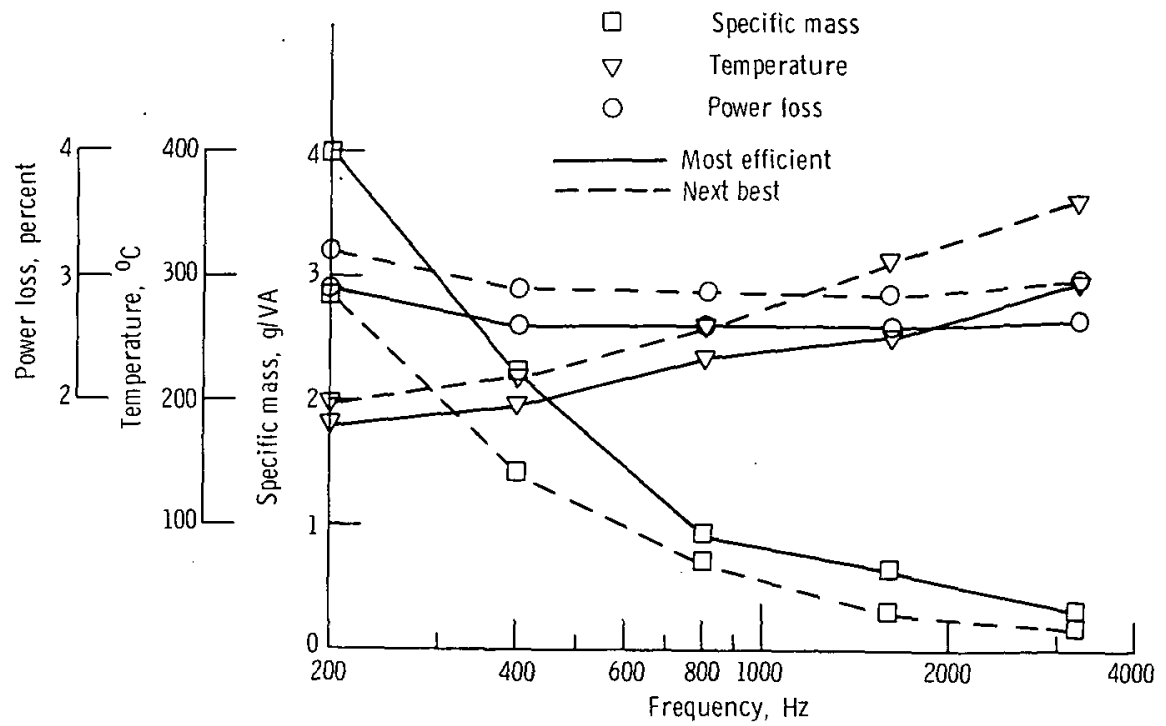

Figure 6. - Comparison of most efficient with next best copper-wound, 4-kilovolt-ampere (32) $2000 \mathrm{~V}$ ) transformer designs. Supermendur core; ambient temperature, $127^{\circ} \mathrm{C}$; fill factor, 0.5 . 


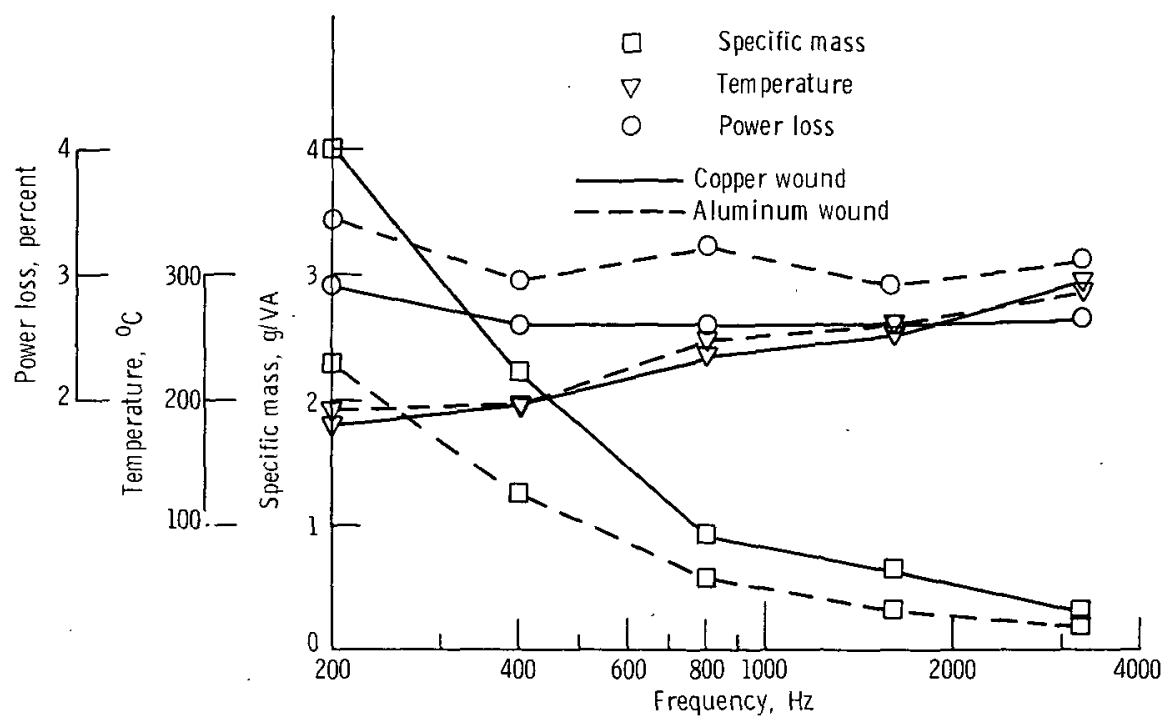

Fiqure 7. - Comparison of most efficient copper-and alum in um-wound 4-kilovolt-ampere (32/2000 V) transformers. Supermendor core; ambient temperature, $127^{\circ} \mathrm{C}$; fill factor, 0.5 .

An estimate of the increase in core losses for temperatures in excess of $250^{\circ} \mathrm{C}$ may be made from the data published by Keuser et al (ref. 9). For $363^{\circ} \mathrm{C}$, the highest temperature design in table II, the core losses may be underestimated by approximately 25 percent. At the other high temperatures the estimated core loss errors are $316^{\circ}$ and $313^{\circ} \mathrm{C}, 12$ percent; and $295^{\circ}$ and $290^{\circ} \mathrm{C}, 6$ percent.

An estimate of the temperature change across the transformer windings may be made by assuming a parallel plane model. For the highest temperature case in table II the temperature change between the surface of the transformer and the surface of the core would be less than $7^{\circ} \mathrm{C}$. Temperature variations within the core may be calculated using an expression derived by Carslaw and Jaeger (ref. 10). For the same case the hottest point within the core is $3^{\circ} \mathrm{C}$ above the core surface temperature. Therefore, the hottest point in the core would be approximately $10^{\circ} \mathrm{C}$ above the surface temperature, an increase in the rise above ambient only 4 percent greater than at the surface.

The variation in the properties of the most efficient designs for a change in nominal fill factor from 0.5 to 0.2 are illustrated in figure 8 . The transformers with an FF of 0.2 are approximately 1 percent lower in efficiency, run somewhat hotter, and in all but one case are lighter.

The program allows for the application of insulating tape between-primary-and secondary windings and between layers within the secondary. For the same core and current density this results in a heavier, less efficient transformer since the secondary coil must be longer to accommodate the added bulk of the tape. However, the resulting increase in surface area permits the transformer to operate at a lower temperature. 


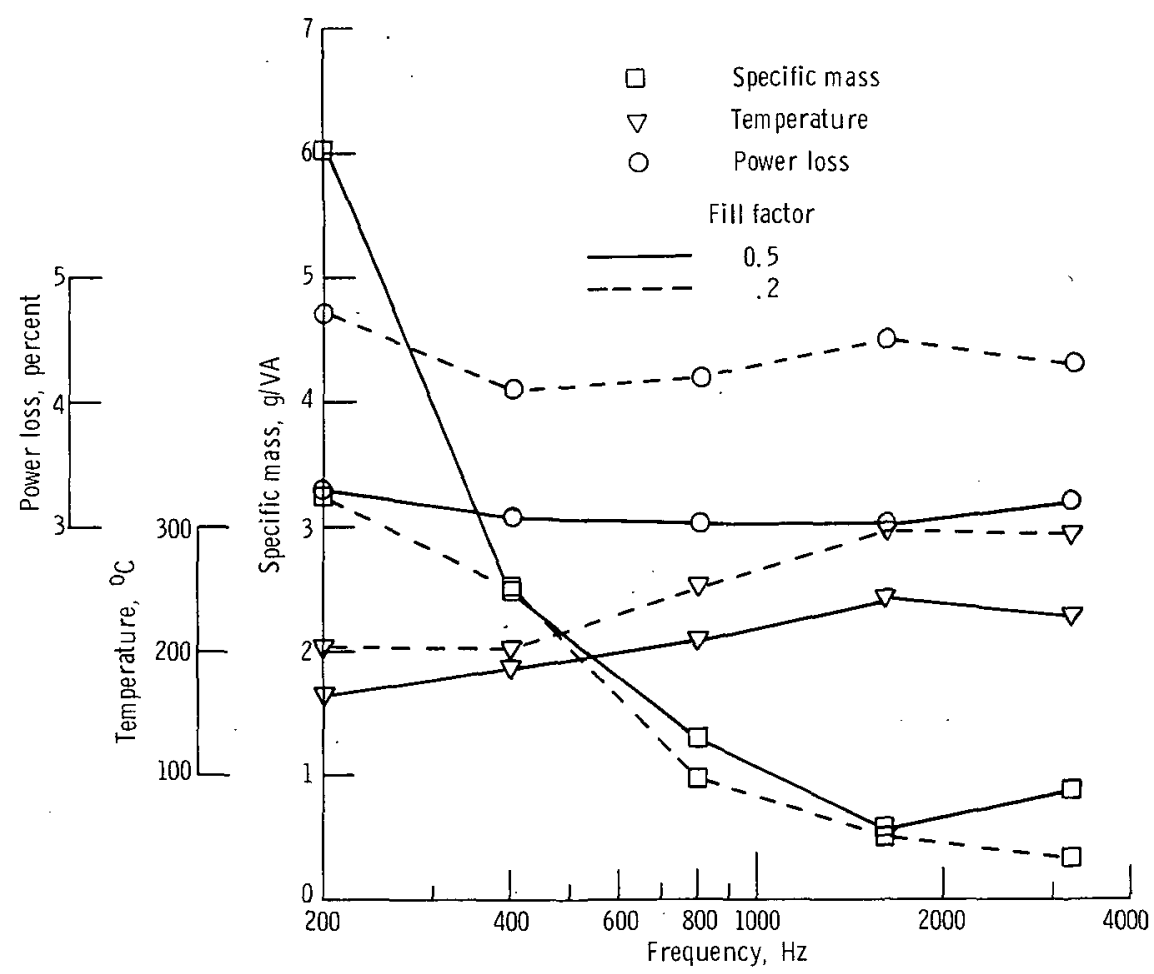

Figure 8. - Comparisons of most efficient designs with nominal fill factors of 0.5 and 0.2 for 2-kilovolt-am pere (16/2000) transformers. Supermendur core; copper coils; ambient temperature, $127^{\circ} \mathrm{C}$.

The result of adding tape at a thickness of $150 \mathrm{~V} / \mathrm{mil}$ to the 2 -kilovolt-ampere transformer design is represented in figure 9 as a comparison of the most efficient designs with and without tape. It can be seen that the most efficient designs with tape are slightly less efficient and heavier, while operating at a lower temperature. This reduction in temperature tends to lower resistance, somewhat offsetting the increase in resistance due to increased conductor length. The weight of the tape is not included in the estimate of transformer mass. 


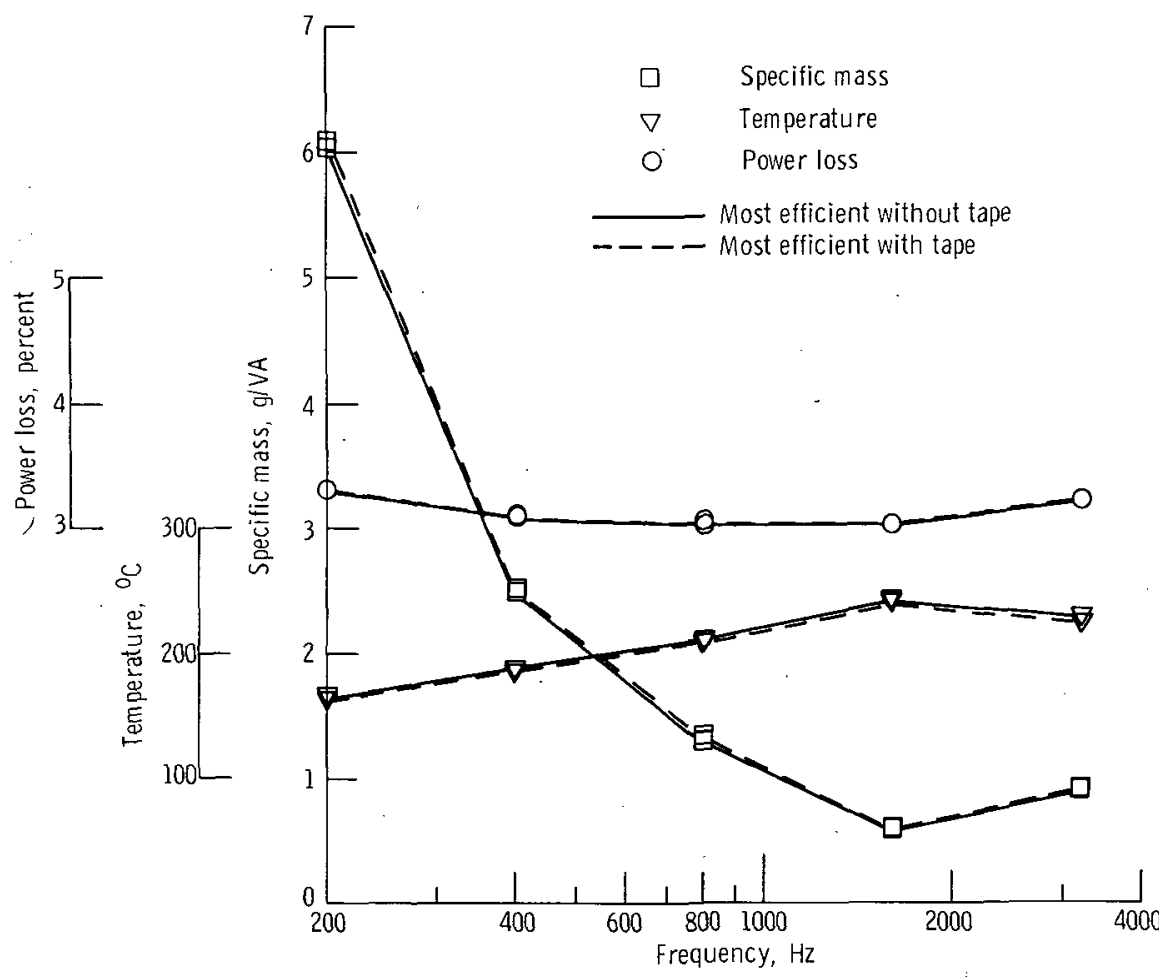

Figure 9. - Effect of adding tape between primary and secondary windings and between layers in secondary winding for 2-ki lovolt-ampere, copper-wound transformers. Supermendur core; ambient temperature, $127^{\circ} \mathrm{C}$; fill factor, 0.5 .

\section{INVERTER EFFICIENCY}

The transformer designs discussed have been incorporated into the analysis of a simple inverter circuit by combining the computed transformer characteristics with estimates of transistor parameters based on manufacturers data. The transistor losses $P_{t}$ are computed approximately using the equation (ref. 11):

$$
P_{t}=\left(I_{S A T} V_{S A T}+2 I_{C R} V 1\right)\left[1-F\left(t_{r}+t_{f}\right)\right]+0.667 V_{1} I_{S A T} F\left(t_{r}+t_{f}\right)+I_{B} V_{B E}
$$

For purposes of this calculation the 1401-0425 transistor is used with $\mathrm{I}_{\mathrm{SAT}}=125 \mathrm{am}$ peres, $\mathrm{V}_{\mathrm{SAT}}=0.7$ volts, $\mathrm{I}_{\mathrm{CR}}=10$ milliamperes, $\mathrm{V} 1=16$ or 32 volts, $\mathrm{t}_{\mathrm{r}}+\mathrm{t}_{\mathrm{f}}=15 \mathrm{mi}-$ croseconds, $I_{B}=5$ amperes, and $V_{B E}=0.95$ volts. When the transistor and transformer losses are combined, it_can be seen in figure_10(a) that the-basic-dissipation-in-....... the simple 2-kilovolt-ampere inverter remains under 8.6 percent up to 1.0 kilohertz before switching losses in the transistors become a major factor. For the 32-volt, 4-kilovolt-ampere system shown in figure 10(b), losses remain under 6 percent to about 1.0 kilohertz. 


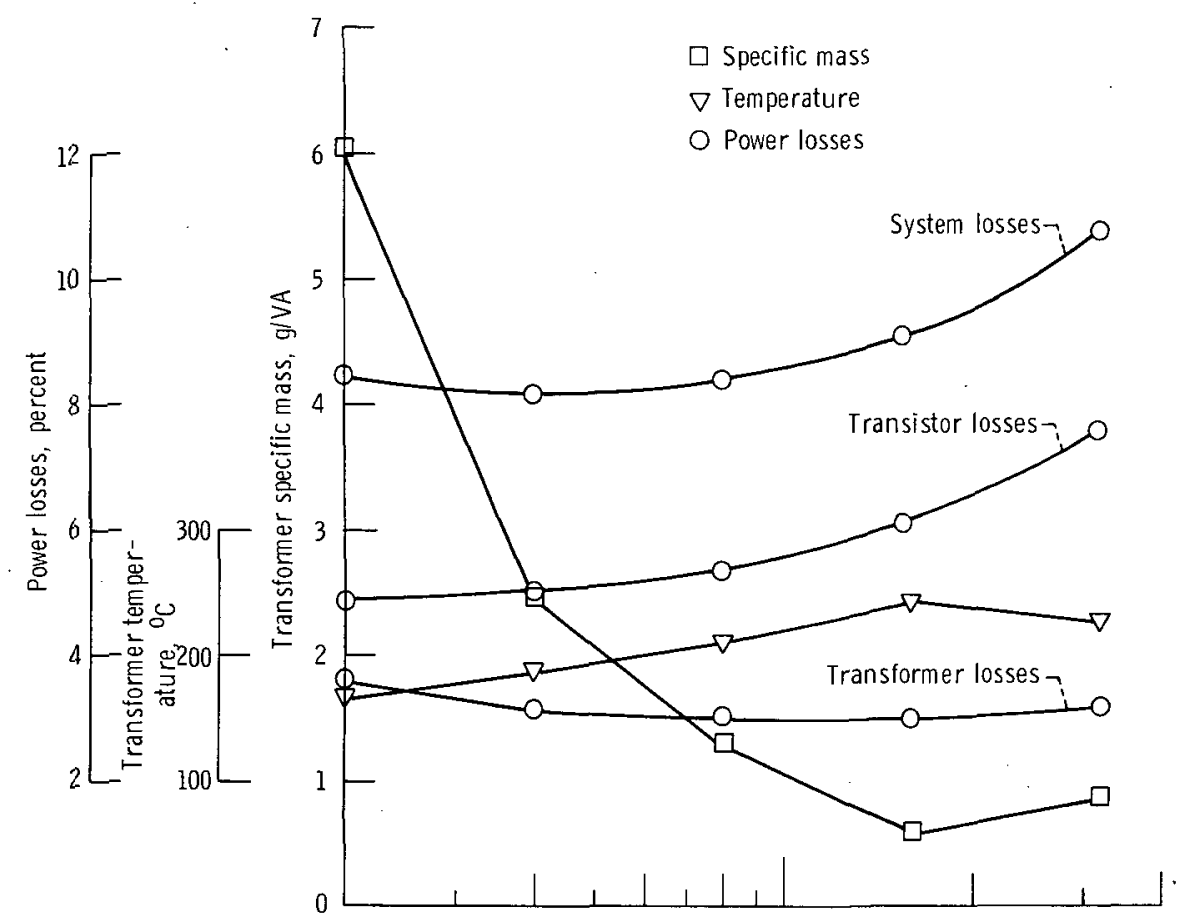

(a) 2-kilovolt-am pere transformers.

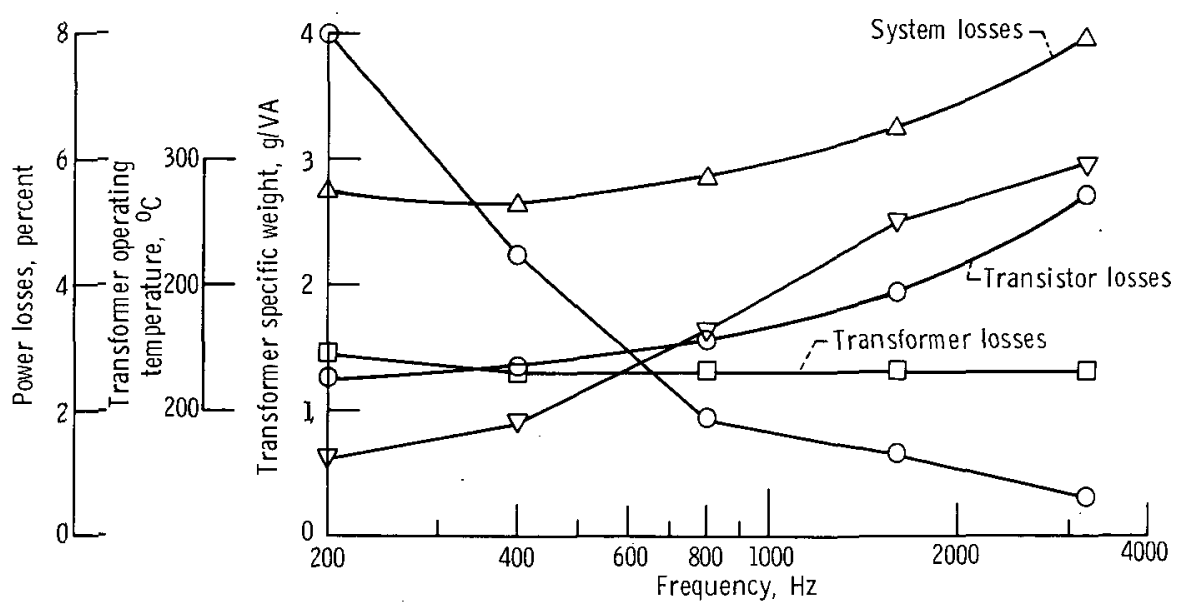

(b) 4-kilovolt-ampere transformers.

Figure 10. - Inverter system properties for most efficient, copper-wound transformers with Supermendur cores. Ambient tem perature, $127^{\circ} \mathrm{C}$. 
The losses in the circuit that provides the base drive for the transistors, whether it be a saturable transformer or an external function generator, are not considered in these estimates. However, this circuit must supply only 4 percent of the current at 3 to 6 percent of the voltage that the power transistors handle so that even if it is only 50 percent efficient it would increase losses by only 0.24 or 0.12 percent in the 16 - or 32-volt systems, respectively.

In a typical complete inverter system (ref. 12) additional reductions in efficiency of approximately 5 percent have been experienced because of losses in the regulation and filter circuits.

\section{CONCLUSIONS}

The computer program described here carries out the necessary calculations for the design of toroidal transformers made with tape wound cores and standard round wire. Any magnetic material may be used in the core, and any round metal wire may be used in the coil. The transformer has a single secondary coil and a center tapped primary. The output of the program contains considerable detail about the specifications and operating parameters of the transformer. Running time on the IBM 7094 is approximately 0.0011 minute per transformer.

When the program is employed in the design of transformers for 2.0- and 4.0kilovolt-ampere inverters, it is found that over a range of frequencies from 200 to 3200 hertz, the efficiency of the most efficient transformer at each frequency varies by only a few tenths of a percent. Tränsformer weight drops nearly linearly with frequency, and temperature rises with increasing frequency, but at much less than a linear rate.

Savings in transformer weight are illustrated by using either the "next best" rather than the most efficient design, by winding the transformer with aluminum rather than copper wire, and by the use of heavier, lower-reluctance magnetic cores. Each of these savings in weight is generally accompanied by a lowering in efficiency and an increase in operating temperature, however.

Application of the most efficient transformer designs to inverter systems using 1401-025 transistors indicates a basic loss at 1000 hertz for the 16-volt, 2-kilovoltampere system of 8.6 percent and for the 32-volt, 4-kilovolt-ampere system, 6.0 percent.

These calculations indicate that the most efficient transformers will operate at temperatures $40^{\circ}$ to $170^{\circ} \mathrm{C}$, in excess of the ambient of $127^{\circ} \mathrm{C}$. In calculating temperature it is assumed that the entire outside surface of the transformer will be free to radiate and that the emissivity is 0.95 . If, for example, only 50 percent of the surface is able to radiate, then the temperature estimates need be revised upward by approximately 
19 percent. Furthermore, the temperature is only an estimate and does not take into account the presence of hot spots. However, these temperatures still do not approach the upper limits of available magnetic materials and insulation (ref. 13). Furthermore, no provision has been made in the computation of temperature for any heat transfer due to conduction through mounting brackets or a heat sink or to convection if the transformer is not to be operated in a vacuum.

Lewis Research Center,

National Aeronautics and Space Administration,

Cleveland, Ohio, March 29, 1972,

112-27. 


\section{APPENDIX A}

\section{HEAVY AND LIGHT MAGNETIC CORES}

Two physical properties of magnetic cores, mass and reluctance, appear to have a strong influence on the operation of transformers in which they are used. A heavier piece of magnetic material will generally result in a transformer with greater losses at higher frequencies or lower current densities where iron losses become predominant. Two magnetic cores may have the same or nearly the same window-area core-area product and yet be quite different in mass, the heavier generally being more compact or squat, usually having a lower ratio of inside to outside diameter. However, the heavier core will tend to have a lower relative reluctance magnetic path where relative reluctance $R^{\prime}$ is defined:

$$
\mathrm{R}^{\prime}=\pi \frac{(\mathrm{ODI}+\mathrm{DII})}{(2 \mathrm{AC})}
$$

Because of the higher reluctance usually associated with the lighter cores, transformers made with them must generally have more turns and, therefore, heavier coils, which leads to the result that transformers made with the lighter cores tend to be heavier.

Therefore, if magnetic cores are simply arranged in order of increasing WAC, as done previously (ref. 3), the resulting transformer designs will vary erratically in mass, efficiency, and temperature.

AIEE Standard No. 430 (IEEE Standard No. 104, ref. 14), published in 1958, recommends 21 tape wound toroidal magnetic cores and separates them into two groups; high-gain cores, distinguished by having a ratio of inside to outside diameter greater than 0.70 , and low-gain cores, which have a diameter ratio less than 0.70 . Today, a typical manufacturer's catalog may describe hundreds of cores, and it is an aid in designing an optimum transformer to have a large number of cores from which to choose.

For the cores recommended by the AIEE standard, the diameter ratio distinction is clear cut in terms of weight being greater and reluctance less for low-gain cores, but only 15 of the recommended cores are within the range of WAC considered here. The cores presently available come in a much larger variety of heights and diameters so that a simple delineator such as the diameter ratio cannot adequately separate the data into two distinct groups unless a great many cores are eliminated. The magnetic cores used in the program are available from a variety of manufacturers, in most cases as catalog items. They have been separated somewhat arbitrarily into two groups of 45 each, called light (high-gain), numbered 101 to 145, and heavy (low-gain) cores, numbered 201 


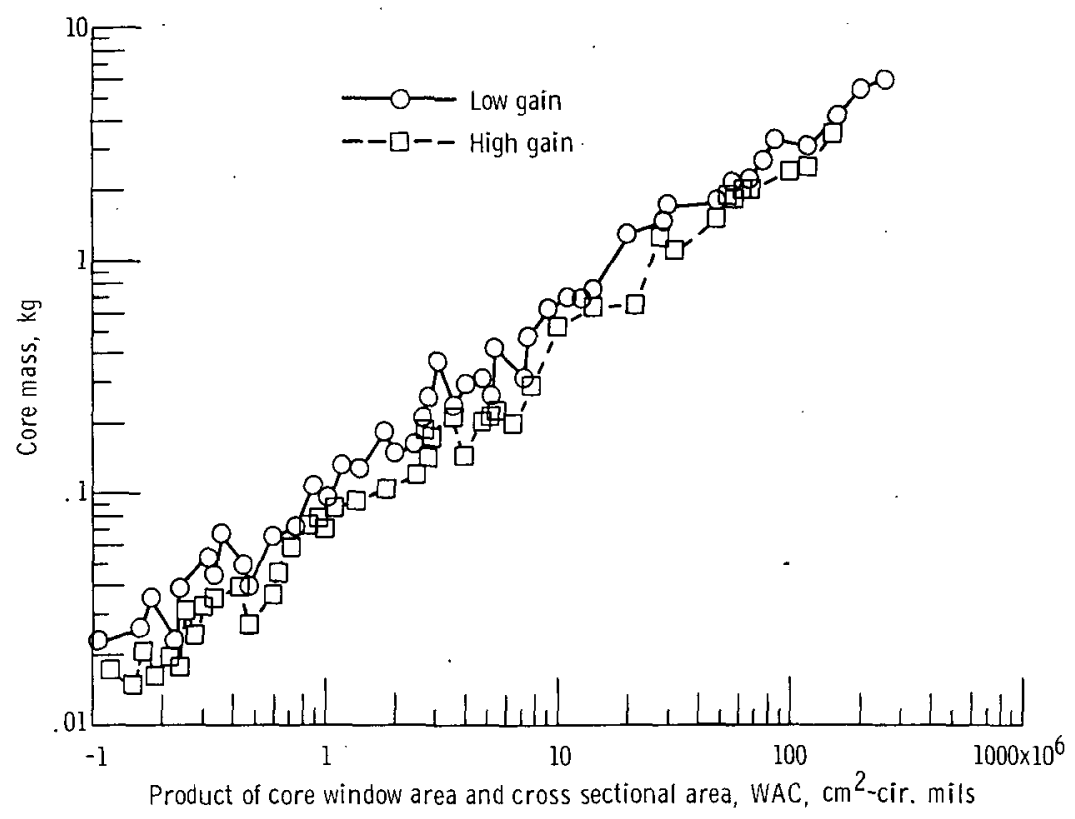

Figure 11. - Variation of core mass.

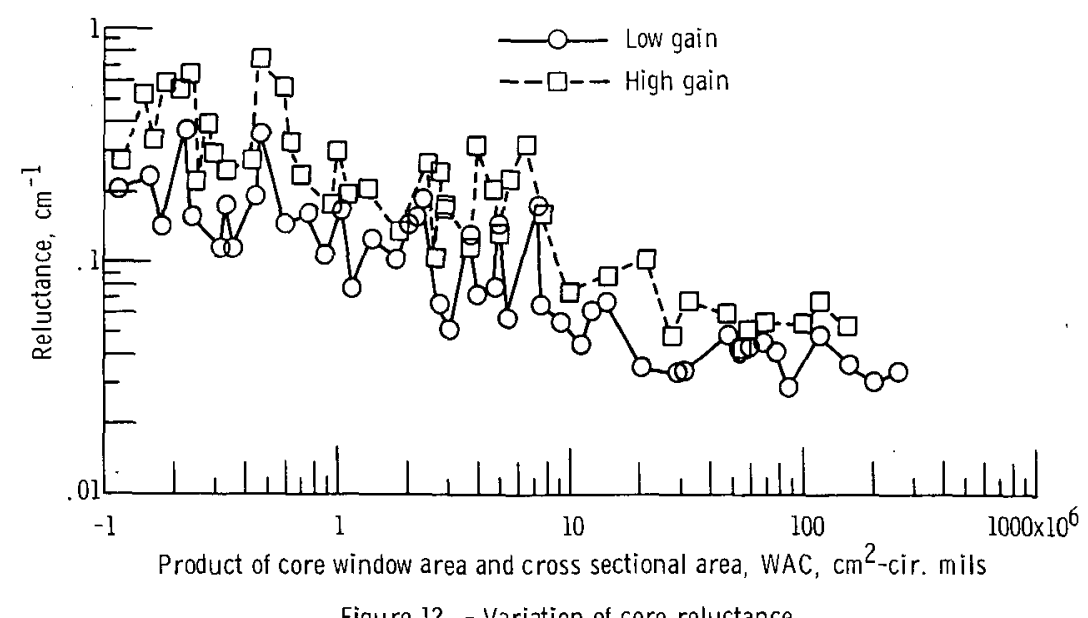

Figure 12. - Variation of core reluctance.

to 245. The distinction between them is that the heavy cores are more massive for approximately the same WAC and usually have smaller ratios of inside to outside diameter. The plot of core mass against WAC shown in figure 11 with 2.0-mil Supermendur as the magnetic material illustrates the greater mass of the low-gain cores, while also indicating that the distinction is not clear cut in every case.

A consequence of this new designation is that core numbers 109, 133, and 136, which were classified by AIEE as low-gain, are included here in the light or high-gain listing and that core numbers 204 and 228, classified high-gain by AIEE, are heavy or low-gain in this listing. 
The squat shape of the heavy cores causes them to have a smaller relative reluctance in all but two cases as seen in figure 12 .

The user may produce a deck of core data cards with any specifications or manufacturer's data desired, following the format used here. If a deck of other than 45 cores is required, the appropriate do loop and iteration limit statements should be altered accordingly. 


\title{
APPENDIX B
}

\section{PROGRAM LISTING}

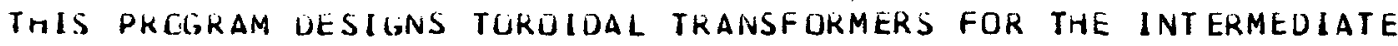
PIIWER RANGE

IGIIKNII IS THE COIRE SEKIAL NUMBEK

WITL. IS THE INSIUE DIAMETER UF THE CORE BOX IN INCHES

WITT IS THF OUTSIDE UIAMETER OF THE CORE BOX IN INCHES

HTT. IS THE HEIGHT DF THE COKE BCX IN INCHES

WA IS TRE WINUOUW AREA IN CIR. MILS. $\$ 1.0 E 6$

AC: IS THE fFFeCTIVE COKE LRUSS SECTIONAL AREA IN CM SUUARED

WAC. IS THE PRUDIICT OF WA ANO AC

MII IS THE INSIDE DIAMETEK OF THE CURE IRON IN INCHES

UUI IS THE DUTSIDE DIAMETER OF THE COKE IRON IN INCHES

HTI IS THF HEIGHT OF THE CORE IRUN IN INCHES

WI MENSIGN ICURNO(45), OITC(45), OOOT(45), HTT(45), WA $(45)$, AC (45),

I WAC (45). OI ( $(45)$. ODI (45).HTI (45)

$c$
$c$
$c$
$c$
$c$
$c$
$c$
$c$

IAWG IS THE STANDARO WIRE GAUGE NUMBER

WAC.I IS THE AREA UF THE CONOUCTING PORTION UF THE WIRE IN CIR. MII.S.

WiC: IS THE BIAMETER OF THE CLNOUCTING PCRTION OF WIRE IN INCHES

AWT IS THE TJTAL WIKE AKEA IN CIR. MILS.

AWT IS THE TOTAL WIKE AKEA IN C.M.

UDM IS THE WIRE RESISTANCE IN UHMS/1000.0 FT FOR COPPER

CONPP IN IS THE WIKE WEIGHT IN POUNDS/1000.0 FT FOR COPPER

DIMENSILN (AWI $(48)$, WACU (48). DIC (48), AWT(48), OPM(48), CUPPM(48)

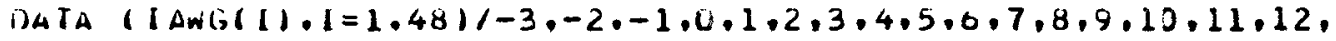

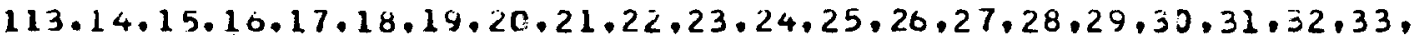

134.35 .36 .37 .38 .39 .40 .41 .42 .43 .441

BATA I WACUIII.I $=1.481 / 211600.0 .167800 .0 .133100 .0 .105600 .0 .83690 .0$, 160300.0 .52620 .0 .41740 .0 .33090 .0 .26240 .0 .20820 .0 .16515 .0 .13090 .0$. $1103 \times 0.0 .8230 .0 .6530 .0 .5180 .0 .4110 .0 .3260 .0 .2580 .0 .2450 .0$. $11620.0 .1290 .0 .1020 .0 .812 .0 .640 .0 .511 .0 .404 .0,320.0 .253 .0 .202 .0$, $1154.0 .128 .4 \cdot 104.0 .79 \cdot 2 \cdot 64 \cdot 0 \cdot 5 c \cdot 4 \cdot 39 \cdot 7 \cdot 31.4,25 \cdot 0.20 \cdot 2 \cdot 16.0$, $112.7 .9 .61 \cdot 7.84 .6 .25 .4 .84 .4 .01$

DATA (DIC. ( 1$) .1=1.48) / 0.40 .0 .4096 .0 .3648 .0 .3249 .0 .2893 .0 .2576$. $10.2294 \cdot 0.2043 .0 .1819 .0 .162 . c .1443 .0 .1285 .0 .1144,0.1019,0.0907$. 1 w.0808.0.072.0.0041.0.0571.C.0508.0.0453.0.0403.0.0359.0.032, $10.112 \times 5.11 .0253 .0 .0226 . L .0261,0.0179 .0 .0159 .0 .0142,3.0126 .0 .0113$, $1 \omega .01 .0 .0089 .0 .008 .0 .0071 .0 .4063 .0 .0056 . C .005 .0 .0045 .0 .004$. $10.0035 \cdot 0.0031 \cdot 0.0028 .0 .0025 .0 .0022 .0 .0021$

LATA (AWT(I) I $=1.48$ )/22C712.C.175393.0.139428.0.110889.0.88209.0, $170172.0 .55838 .0 .44 C 16.0 .35044 .0 .27922 .0 .22231 . \mathrm{C} .17742 .0$. 114137.0 .11257 .0 .8987 .0 .7174 .0 .5730 .0 .4651 .0 .3709 .0 .2970 .0 . 12381.0 .1910 .0 .1529 .0 .1232 .0 .966 .0 .790 .0 .640 .0 .515 .0 .412 .0 .331 .0 . $1709.0 .216 \cdot 0.177 .0 .142 .0 .117 .0 .90 \cdot 6.77 \cdot 0.61 \cdot 0,49 \cdot 0.40 .0 .32 .0$. $120.0 .24 \cdot 0.10 .0 .13 .0 .10 .0 \cdot 0.01 .7 .61$

BATA IDPMI I ). I =1.48) /U.C4401,0.06182.0.07793,C.09825,0.1239. $10.1503 . C .1971 .0 .2485 .0 .3134 .0 .3952 .0 .4981 .0 .0281 .3 .7925$.

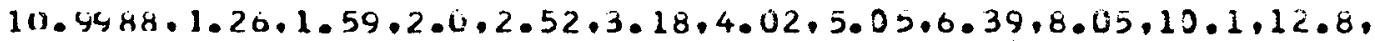
$116.2 .20 .3 .25 \cdot 7.32 .4 .41 .6 .31 .4 .65 .3 .81 .2 .1 C 4.0 .131 .0 .162 .0$. 1200.0 .201 .0 .331 .0 .415 .0 .512 .0 .048 .0 .847 .0 .1080 .0 .1320 .0 . $11600.0 .2140 .0 .2596 .06)$

JATA ICIIPPM(I) I $=1.48) / 64 L .5 .507 .8 .402 .8 .319 .5,253.3 .200 .9$, 


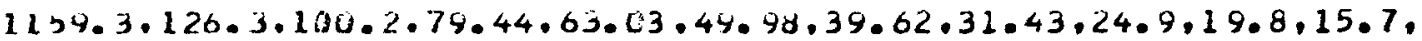
$112 \cdot 4 \cdot 9 \cdot 87 \cdot 7 \cdot 81 \cdot 0.21 \cdot 4 \cdot 92 \cdot 3 \cdot 9 \cdot 3 \cdot 1 \cdot 2 \cdot 46 \cdot 1 \cdot 94,1 \cdot 55 \cdot 1 \cdot 22 \cdot 0 \cdot 97$. $10.765,0.610 .0 .481 .0 .367,0.303 .0 .240 .0 .194 .0 .153 .0 .12,0.0949$, 10.0757 .0 .0613 .0 .0484 .0 .0371 .0 .0291 .0 .0237 .0 .0189 .0 .0147 .0 .01211 $\checkmark I$ IS THF INPUT VOLTAGE IN VULTS $\checkmark ?$ IS THE OUTPUT VULTAGE IN VULIS CURI IS THE INPUT CURRENT IN AMPS F IS THE OPERATING; FREOUENCY IN HERTZ PGIMAXX IS THF MAXIMUM POWER CUNSUMPTIUN ALLUWEU PER. COIL IN WATTS WIMAX IS THE SPECIFIED MAUNETIC FLUX DENSITY IN GAUSS D)FISSTY IS THE DESITY UF THE CORE IRUN IN POUINDS/CUBIC INCH TAPEV IS THE RATED VDLTAGE PER MIL FOR INSULATING TAPE WATHP IS THE LUKE LOSS IN WATTS PER POUND VAPP IS THE APPAKENT CÖRE PUWER IN VOLT-AMPERES PER POUND TAMB IS THF AMBIENT TEMPEKATURE IN UEGREES CENTIORAUE CU EUUALS 1.0 IF THE COILS ARE COPPER. EUUALS O.0 IF ANOTHER CIINIJUCTOK IS USED

a EwUals 0.0 If the coIls are copper. ecuals 1.0 If andther GRINIIUC.TRIR IS USED KUENS IS THE DENSITY LF AN ALTERNATE CUNDUCTOR, RELATIVE TU COPPER RRES IS THF RESISTANCE OF AN ALTERNATE CUNOUCTOR. RELATIVE TO C.TIPIFK

TEMCONK IS THE TEMPERATURE COEFFICIENT OF RESISTANCE OF ALTERNATE CIINOUUICTOK IN IIHMS PER DEGREE CENTRIGRADE AT 20.0 C C.MPA SPECIFIES THE DESIREU INVERSE CURRENT DENSITY IN CIR. MILS. PFR $\triangle M P$

INAMFLIST/IN/VI, V2, CURI, F, PCUMAX, BMAX, DENSTY, TAPEV, WATPP, IVAPP. TAMH: Fr, CU. A. KDENS, RRES, TEMCOR, CMPAIOUTIVI, V2, CURI. 1C.UR2, CUREX, NP. IAWG1, NWRAPI, K1, PCUL1, CUWAT1, FF, IAWG2, NS, INWKAP2. R2, PCU2, CUWAT2, XLONG1, XLOING2, ICORN, CORWAT, PIRON, 1KEIOUL. FLUSS, EFISH, TOTWAT, FILF, TAMB, T, FOD. FHTT, F, SURFT, IVZFI. WATTPA. CMPA. CU, A. BUSEO/TROBLE /I SORCE/CORUTA/ ICORNO. LDITC. DCT. HTT, WA. AC. WAC, DII, OUI, HTI

: COUK? IS THF DUTPUT CURRENT IIN AHPS

C.UREX IS THE EXCITATION CURRENT IN AMPS NP IS THF NUMMER OF PRIMARY TURNS

IAWIil IS THE WIRE GAULE CHOSEN FOR THE PRIMARY COIL IAWGi? IS THE WIKE GAUGE CHOSEIN FUR THE SECONOARY CUIL IVS IS THF NUMOER LF SECONLARY TURNS

WKAP I IS THE NUMAER UF PAKALLEL WLINUINGS IN THE PKIMARY WKAP 2 IS THE NUMBEK OF PARALLEL WINUIINGS IN THE SECUNOARY KL IS THF PKIMARY RESISTANCE IN UHMS

K2 IS THE SECIJNDARY RESISTANCE IN UHMS

PC.UI IS THE POWER OISSIPATEO IN THE PRI MARY IN WATTS

PCU2 IS THF POWER UISSIPATEO IN THE SEC CNUARY IN WATTS

CWMATI IS THE WASS UF THE PRIMARY COIL IN KILOGRAMS

CHWAT2 IS THE MASS OF THE SECONOAKY COIL IN KILUGKAMS

COINWAT IS THE MASS LH THE CORE IRUNN IN KILOGRAMS

PIRON IS THE COKE LUSS IN WWTTS

REIBIL IS THE REGULATION IN PEK CENT

PLLISS IS THE TUTAL TKANSFORMER LOSS IN WATTS

FFISH IS THE TKANSFORMER EFFILIENCY IN PER CENT

TOTWAT IS THF TUTAL WEIGHT UF THE TRANSFURMER

FILF IS THE FINAL FILL FACTOR

FIHU IS THE FINAL OUTSIUE OIAMETER IN CM

FHIT IS THE FINAL HE IGHT IIN CM

T IS THE DPERATING TEMPERATURE IN DE GRE ES CENTIGRADE

SURFT IS THE FINAL SURFACE AREA IN SDUARE CM

WATTPA IS THE RATIO OF LUSSES TO SUKFACE AREA 


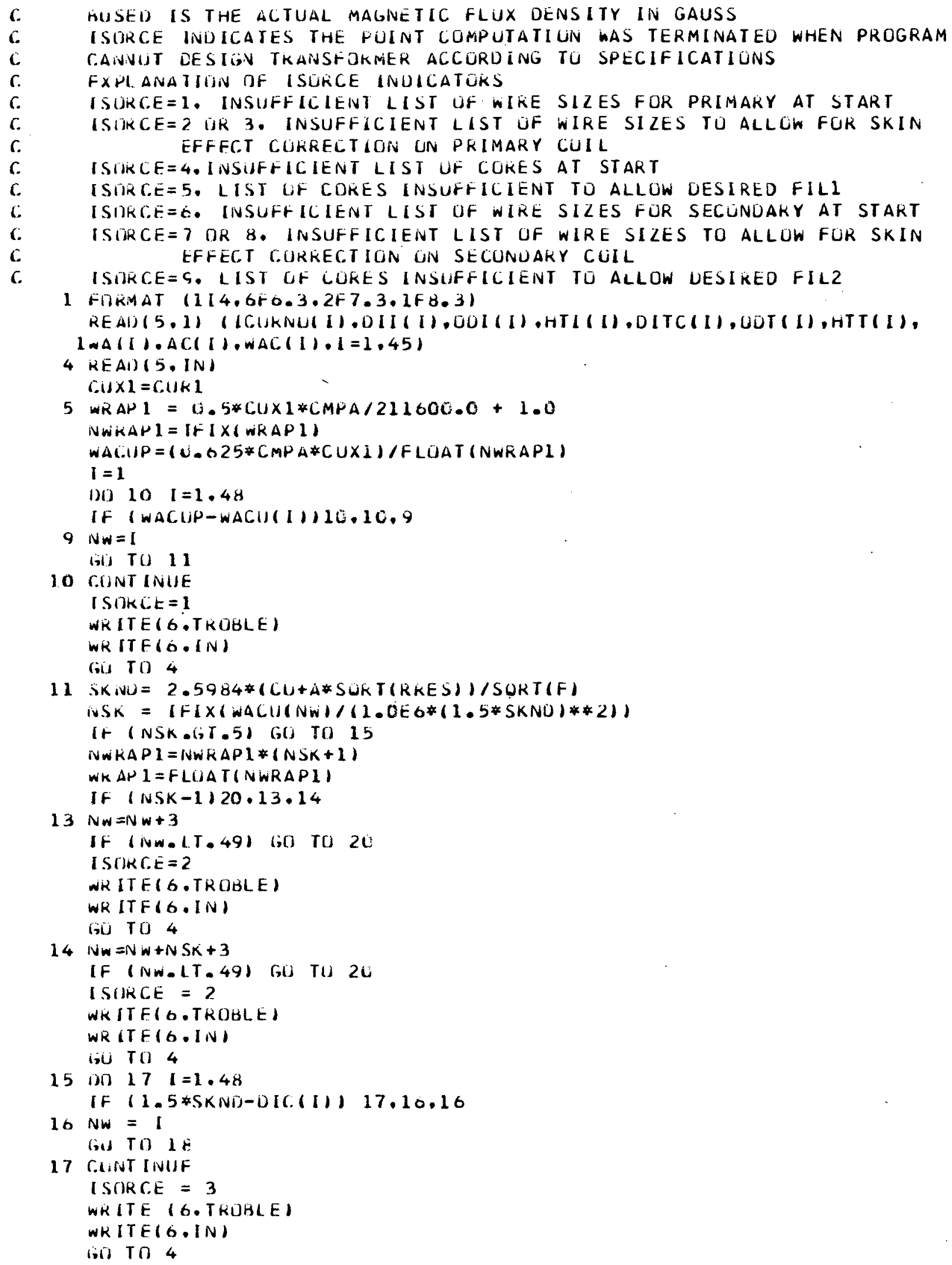


18 NWKAP $1=$ IF $[\times(0.5 * C U X) * C M P A / W A C U(N W)+1.0)$

WRAP 1 = FLUAT (NWRAP I)

20 WCI $=10 Q . U * V L * A H T(N N) * W R A P 1 /(F * F F * B M A X)$

$J=1$

21 औI $23 \quad J=1.45$

IF ( WAC (I-WAC( $)]) 22.22 .23$

22. $N C=J$

(Bi) TOS 3C

23 C.RINT INUE

I $S O R C E=4$

WRITE(6.TKOBLE)

WKITE(G,IN)

(B) TII 4

30 .NP $=2 *(I F[X(V) * 0 . \angle 5 E B /(F * A C(N C) * B M A X)+0.8))$

$N N=F L U A T(N P)$

nUSF $D=V 1 * 1.0 E O /(2, C \# P N \# F \# A C($ INC $))$

$40 \mathrm{~F}(L L=P N * W R A P 1 * A W T(N W) /(W A(N C) * 1$. EO)

$A i)=U I(C,(N C) * S W R T(1, C-F I L L)$

TAPEXP = FLCIAT (IF (X) (V $1+V 2) / T A P E V))$

$A U=A D-T A P E X P / 500.0$

$F[L 1=1 . C-A D * 2 / D I T C(N C) * 2$

$F F 1=0.64 * F F$

IF (FILI.GT.FFI) GO TO 41

SiU TO 50

$41 N C_{0}=N C_{0}+1$

IF (NC.ELT.40) GO TO 30

I SUR CE $=5$

WRITE(6.TKUBLE)

WKITEE (G.IN)

(iI) TO 4

$50 \times L G N(S)=P N * 12.0 * H T T(N C)+O O T(N C)+O I T C(N C) *(1.0-2.0 * S O R T(1 . C-F I L L))$

$54 R U 1=\operatorname{OPM}(N W) * X L G i N G 1 *(C U+A * R R E S) /(24000.0 *$ WRAP 1$)$

$K l=R 01 *(1.0+(C U * C .00393+A * T E M C O R) *(T A M B-20.0))$

$55 P(, 1) 1=K 1 \neq C, U R 1 * 2$

5o IF (PCU1-2.0*PCUMAX) 00.60 .57

$57:$ : $U \times 1=1 \cdot 1 *$ CUX1

iiii TO 5

60 $S N=C .5 * N+V 2 /(V 1-2 . U *(U K L * K I)$

$N S=I F I X \mid S i N)+1$

SN $=$ FLUAT T NSI

C.UKWAT $=3.14159 * H T$ I INC) $*$ UENSTY*(UDI (NC)*2-OII $(N C) * 2) / 4 . C$

C.UKF $X=V A P P * C O K W A T * \Delta U S E D /(V I * B M A X)$

C.UKR $=P N * 0.5 *($ CUK $1-$ CUKEX $) / S N$

r.UN2 $=$ C.UK2

61 NWKAP $2=[F[\times(615 \times 2 * C M P A / 211600.0+1.01$

62. WKAP $2=$ HINAT (NWKAP 2$)$

WAC.US $=1.25 *$ M.MPA*CUN2 /FLUAT(NWRAP2)

$63 \mathrm{~m}=1$

DU $70 \quad M=1.48$

IF I WACUS-WACUIM $170,70.64$

$64 \quad M W=i 4$

(i) TO 80

70 CIINT INUE

I SIIKCEE $=6$

WR ITE(G.TKIDIE)

WR ITF(O.IN)

(i) $\mathrm{TO}_{4}$ 
BO MSK = IFIX(WACU(MW)/11.0EO*(1.5*SKND)**2)

NiRAP $2=$ NWRAP2 $2(M S K+1)$

WRAP ? = FLחAT (NWRAP2)

IF (MSK.GT.5) GU TO 85

If $(M S K-1) 90.83 .84$

$83 M w=M w+3$

IF $(M W . L T .49) G O$ TO $9 C$

ISURC:F $=7$

WR ITE (6.TROHLE)

WFITE(6.IN)

(B) $\mathrm{TH} 4$

$84 M w=M w+M S K+3$

Ir IMw.LT.49) GÜ TO 90

I SIRCE $=7$

WKITE(G.TRUBLE)

Wh ITF ( 6. IN)

(i) Til 4

85 i) $87 \quad t=1.46$

if $11.5 *$ SKNÜ-1) [C( 1 (1) 67.86 .86

$86 \mathrm{MW}=1$

(ii) TO $6 \overline{8}$

87 C.ONT INUF

I SIJKC:E $=8$

WKITE(6.TKDBLE)

WRITE(6.IN)

IUU TR 4

88 NWKAP $2=I F I \times(C U \times 2 * C M P A / W A C U(M W)+1.0)$

WK $\triangle P 2=$ FLIIAT (NWKAPZ)

$90 F I L 2=S I N * w R A P 2 * A w T(M W i) /(W A(N C) * 1$. EO)

BU $=$ DI TCINC)*SLKTII.O-FILI-F IL2)

TAPEXS=FIUAT(IFIX( V2/TAPEV $)$

SO $=\$ O-T$ APEXS/5OC .0

$r[L F=1.0-B D * \# 2 / 0 I T($ INC) $* 2$

$F F F=1.28 * F F$

IF (FILF.GT.FFF) GU TO 91

(BT) TO 1 LO

$91 N G=N C+1$

IF (NCDET.46) GO TO $3 C$

I $5 \cap R C F=9$

WK TTE (6.THOBLF)

Wh IT E (6. IN)

(i) TO 4

1 GO PIRDN = WATPP*CUKWAT *ULSEO/OMAX

$C=C .5 *($ C.ITC. $(N C)-.A D)$

$a=0.5 *(\Delta U-B D)$

$111 \times \operatorname{LUNG} 2=\operatorname{Siv} *(2.0 * H T T(N C)+8 . C * C+4.0 * B+00 T(N C)-O I T C(N C))$

112 RÜ? = UPM $(\mathrm{WW}) * X L(I N G 2 *(C U+A * K K E S) /(120 \mathrm{~L} 0$ **WRAP 2$)$

$K 2=K O 2 *(1.0+(C \cup * U . C C 393+A * T E M C O K) *(T A M B-20 . C))$

$P(: U 2=K 2 \neq C$ UUR $2 * 2$

IF (PC.U2-PCUMAX) 12C,120.113

$113 \cdot \operatorname{r.v} \times 2=1.1 \div i \mathrm{~L} \times 2$

(i) $T$ T1 61

120 SIJRF $1=3.14154 *(D O T(N C)+U I T C(N C)-B O) *(H T T(N C)+2.0 * C+2.0 * 3)$

SURF $2=3.14159 *($ (UUT $(N C)+2.0 * C+2.0 * B) * 2-B 0 * 2) / 2.2$

SURFT $=(S U R F 1+$ SURF 2$) * 2 \cdot 54 * 2.54$

PI. LSS $S=P$ C.III +PC.1J2 +PIROIV

121 PI.AST $=$ PLOSS

WATTPA $=$ PLUSS / SILRFT

$T=($ WTTPA/Ü.55*5.67E-12)+(TAMÖ+273.0)*4)*0.25-273.0 
$123 K 1=R U 1 *(1.0+(06 * 0.00393+A * T E M C O K) *(I-20.01)$

$P C U 1=R 1 * C . U R L * 2$

IF |PCU1-PCUMAXI125.125.57

$125 * 2=R 02 *(1.0+(C U * 0.00393+A * T E A C O R) *(T-20.0) 1$

$P C$ CIS $=K 2 \# C$ USR $2 * 2$

IF (PCUz-PCUMAX) 130.130.113

130 PL US S $=P C$ CU1 PC.UL $+P I R U N$

IF (PLUSS-1.01*PLAST) 131.131 .121

$1.31 \vee 2 H 1=20 U *(V)-C(I R I * R 1) * S N / P N-C U R 2 * R 2$

IF IVZFL.GT. V2) GU TO 140

$S N=0.5 *(\vee 2+C U R 2 * R 2) * P N /(V 1-C U R 1 * R 1)$

$N S=I F[X(S N]+1$

SiV = FIDAT (NS)

CUR $2=P I N * 0.5 *($ C.UR $)-C U R E X) /$ SN

GO TO 90

140 ICGRiN $=I$ CORIVI) $(\mathrm{NC})$

$\checkmark 20=(V I-C O U R E X * K 1) * 2.0 * S N / P N$

$K$ tind $=100.0 *(V 20-V 2 F L) / V 2 F L$

I AWlil $=$ I AWG( $\left(N_{W}\right)$

IAWLi $2=I A W G(M W)$

CIIWAT $1=x 1$ CIVTi 1 *WRAP $1 *(C 11+A * R U E N S) * C U P P M(N w) /(12000.0 * 2.205)$

C.1WWT $2=X L$ ONGZ $2 * W R A F 2 *(C U+A * R U E N S) * C U P P M(M W) /(12 C 00.0 * 2.205)$

C.UKWAT $=$ CORRWAT/2.205

Fr ISH $=100.0 *(1 . .-P L U S S /(V) * C U R 1)$

TOTWAT = (CONWAT +CUWAT I + LUWATZ)

Fib) $=(O D T(N C)+2.0 * C+2.0 * 6) * 2.54$

FHTT $=($ HTT $(N C)+2.0 * C+2.0 * B) * 2.54$

WE ITF(G.0IUTI

(ii) $\operatorname{Tn} 4$

Fin

SHATA

c

201 THF INFXT 45 CARODS LONTAIN THE UATA

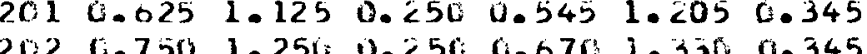

$2020.750 \quad 1.250,0.250 \quad 0.670 \quad 1.350 \quad 0.345$

$2030.050 \quad 1.150 \quad 0.375 \quad 0.575 \quad 1.225 \quad 0.470$

$204 \quad 1.0001 .375 \quad 0.250 \quad 0.915 \quad 1.400 \quad 0.345$

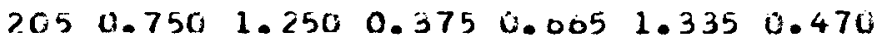

$206 \quad 0.7501 .250 \quad 0.500 \quad 0.670 \quad 1.3350 .605$

$\begin{array}{llllllll}207 & 0.875 & 1.375 & 0.375 & 0.790 & 1.460 & 0.470\end{array}$

$208 \quad 0.750 \quad 1.500 \quad 0.375 \quad 0.665 \quad 1.585 \quad 0.480$

$709 \quad 1.0001 .5600 .375 \quad 0.415 \quad 1.585 \quad 0.470$

$2101.250 \quad 1.750 \quad 0.250 \quad 1.1001 .840 \quad 0.350$

$2111.0001 .500 \quad 0.50000 .9151 .585 \quad 0.605$

$2121.1251 .625 \quad 0.500 \quad 1.6351 .715 \quad 0.610$

$2131.0001 .750 \quad 0.506 \quad 0.9051 .8450 .015$

$7141.2502 .000 \quad 0.375 \quad 1.160 \quad 2.096 \quad 0.480$

$2151.6001 .5001 .000 \quad 0.9151 .5851 .105$

2101.250 2.000 0.5ü 1. i5t: 2.116 i. 015

2171.2502 .250 0.500 $1.1502 .350 \quad 0.020$

$2181.500 \quad 2.250$ L.

$2191.6252 .3750 .5001 .5202 .400 \quad 0.020$

$2201.5002 .500 \quad 0.5061 .38002 .616 \quad 0.620$

2211.2502 .000 1.600 2.1502 .1101 .115

$222.1 .250^{\circ} 2.2501 .0001 .150^{\circ} 2.3501 .215$

$2231.750 \quad 2.750 \quad 0.500 \quad 1.640 \quad 2.060 \quad 0.620$

$2.241 .5002 .250 \quad 1.00112 .3952 .3501 .115$

2251.0252 .375 l.CLL 1.5202 .4801 .115

$2.202 .0003 .000 \quad 0.500 \quad 1.680 \quad 3.1200 .625$

2271.5602 .501 1.6.00 1.38632 .0201 .115

FOR THE HEAVY CURES

$0.308 \quad 0.343 \quad 0.106$

$0.4620 .343 \quad 0.158$

$0.348 \quad 0.514 \quad 0.179$

$\begin{array}{lll}0.865 & 0.257 & 0.2222\end{array}$

$\begin{array}{lll}0.462 & 0.514 & 0.237\end{array}$

$0.462 \quad 0.086 \quad 0.317$

$\begin{array}{llll}0.048 & 0.514 & 0.333\end{array}$

$\begin{array}{lll}0.462 & 0.771 & 0.356\end{array}$

$0.865 \quad 0.514 \quad 0.445$

$1.3690 .343 \quad 0.470$

$0.865 \quad 0.686 \quad j .593$

$1.052 \quad 0.686 \quad 3.749$

$0.865 \quad 1.028 \quad 0.889$

$1.309 \quad 0.771 \quad 1.055$

$0.805 \quad 1.371 \quad 1.186$

$1.369 \quad 1.028 \quad 1.4[7$

$1.369 \quad 1.371 \quad 1.814$

$1.960 \quad 1.028 \quad 2.015$

$2.326 \quad 1.028 \quad 2.391$

$\begin{array}{lll}1.900 & 1.371 & 2.687\end{array}$

$\begin{array}{lll}1.369 & 2.057 & 2.816\end{array}$

$1.369 \quad 2.742 \quad 3.093$

$2.723 \quad 1.371 \quad 3.733$

$1.960 \quad 2.057 \quad 4.032$

$2.320 \quad 2.057 \quad 4.785$

$3.610 \quad 1.371 \quad 4.949$

$1.960 \quad 2.742 \quad 5.374$ 


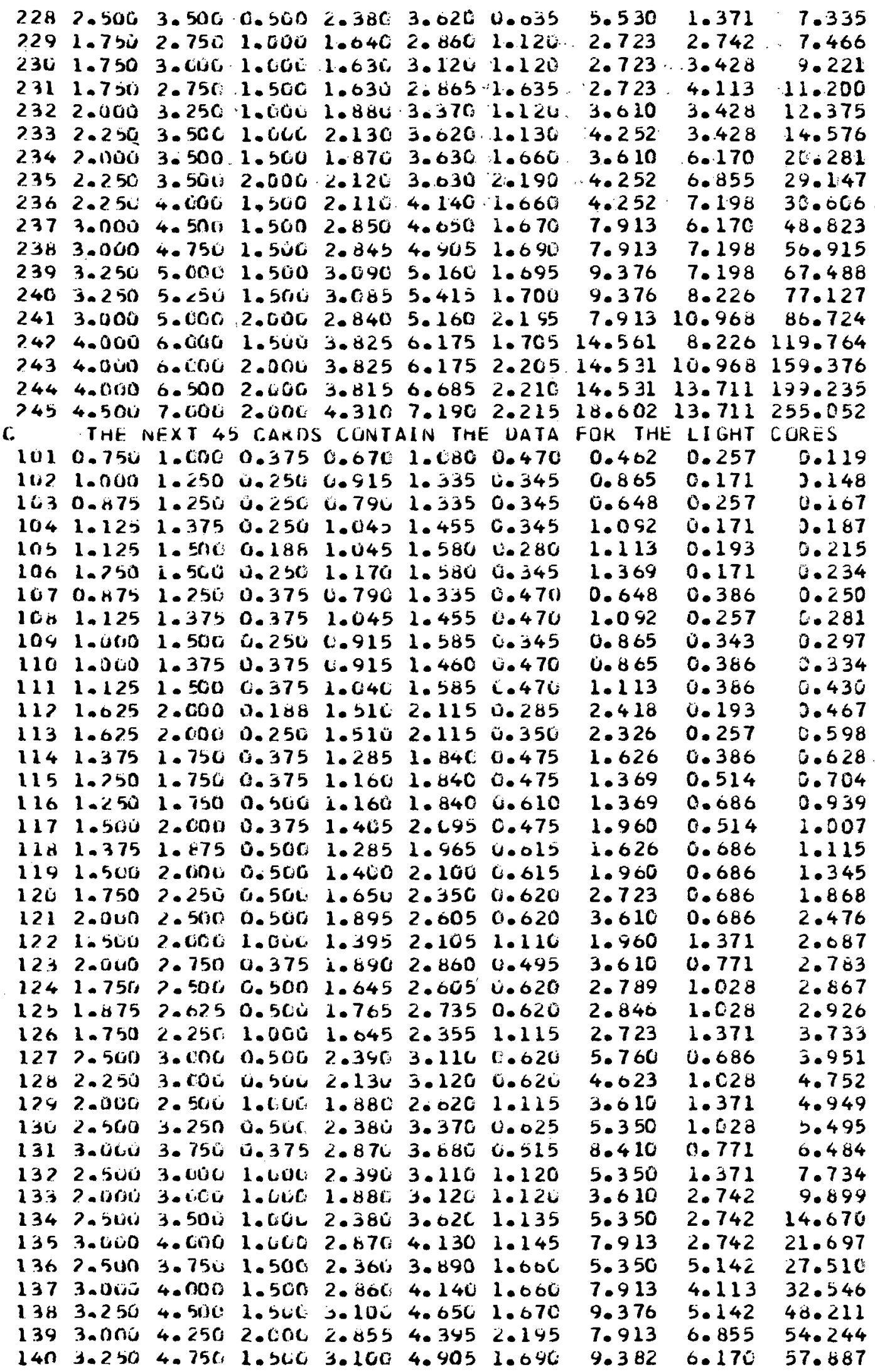




$$
\begin{aligned}
& 1413.250 \quad 4.5062 .000 \quad 3.100 \quad 4.650720009 .376 \quad 0.855 \quad 64.437 \\
& 1423.500 \quad 5.000 \quad 1.500 \quad 3.340 \quad 5.160 \quad 1.695 \quad 10.969 \quad 6.170 \quad 67.679 \\
& 1434.000 \quad 5.2502 .000 .3 .035 \quad 5.415 \quad 2.20514 .539 \quad 6.855 \quad 99.665
\end{aligned}
$$

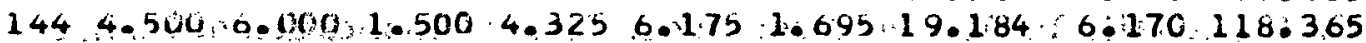

$$
\begin{aligned}
& 145 \quad 4.500 \quad 6.5001 .500,4.3156 .085 .1 .710 \quad 18.593 \quad 8.226152 .946 \\
& \text { C "THE FLLLUWING CAKUS CONTALIN A SAMPLE INPUT STATEMENT } \\
& \text { SIN } V I=16.0 \cdot V 2=20 U L . O . G U R I=125.0, F=200.0, P C U M A X=40.0,0 M A X=18000.0 \text {, } \\
& \text { DENS TY }=0.295 ., \text { ATPP }=6.00, V A P P=7.00, T A M B=127.0 . \text { RRES }=1.0 \text {. }
\end{aligned}
$$

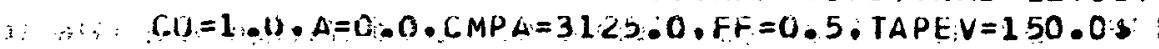

36 
1. Williams, S. B.;-Abetti;. P. A.; and Magnusson, E.-F.: Application of Digital Computers to Transformer Design. AIEE Trans. vol. 75, pt, III, Aug. 1956, pp. $728-735$ :

2. Kusko, Alexander; and Wroblewski, Theodore: Computer-Aided Design of Magnetic Circuits. M.I. T. Press, 1969.

3. Hopper, Donald J.: Computerized Toroidal Transformer Design. IEEE Trans. on Magnetics, vol. MAG-6, no. 1, Mar. 1970, p. 41.

4. Organick, Elliott I.: A Fortran IV Primer. Addison-Wesley Publ. Co., 1966.

5. Ramo, Simon; Whinnery, John R.; and Van Duzer, Theodore: Fields and Waves in Communication Electronics. John Wiley \& Sons, Inc., 1965, p. 293.

6. Knowlton, Archer E., ed.: Standard Handbook for Electrical Engineers. Eighth ed., McGraw-Hill Book Co., Inc., 1949, p. 570.

7. Frost, R. M.; McVay, R. E. ; and Pavlovic, D. M.: Evaluation of Magnetic Materials for Static Inverters and Converters. NASA CR-1226, 1969, pp. 63 and 65.

8. Gould, H. L. B. ; and Wenny, D. H. : Supermendur, A New Rectangular-Loop Magnetic Material. Electrical Eng., vol. 76, no. 3, Mar. 1957, pp. 208-211.

9. Kueser, P. E. ; Pavlovic, D. M.; Lane, D. H.; Clark, J. J. ; and Spewock, M.: Properties of Magnetic Materials for Use in High-Temperature Space Power Systems. NASA SP-3043, 1967.

10. Carslaw, H. S.; and Jaeger, J. C.: Conduction of Heat in Solids. Second ed., Clarendon Press, Oxford, 1959, p. 224, eq. 40.

11. Anon.: RCA Power Circuits DC to Microwave. Tech. Series SP-51, RCA Electronics Components Div., Harrison, N.J., p. 139.

12. Gourash, Francis; Birchenough, Arthur G.; Pittman, Paul F.; Ravas, Richard J.; and Hall, William G.: Development and Performance of Pulse-Width-Modulated Static Inverter and Converter Modules. NASA TN D-6511, 1971.

13. Kueser, P. E. ; Neff, W. S.; and Lane, D. H.: Research and Development Program on Magnetic, Electrical Conductor, Electrical Insulation, and Bore Seal Materials: Electrical Conductor and Electrical Insulation Materials. Rep. WAED64.53E, Westinghouse Electric Corp. (NASA CR-54092), Oct. 1964.

14. Anon.: Proposed Recommended Practice for Toroidal Magnetic Tape Wound Cores, IEEE Standard No. 104 (AIEE Standard No. 430), Apr. 1958. 
"The acronautical and space activities of the United States shall be conducted so as to contribute . . to the expansion of buman knowledge of phenomena in the atmosphere and space. The Administration shall provide for the widest practicable and appropriate dissemination of information concerning its activities and the results thereof."

- National Aeronautics and Space Act of 1958

\section{NASA SCIENTIFIC AND TECHNICAL PUBLICATIONS}

TECHNICAL REPORTS: Scientific and technical information considered important, complete, and a lasting contribution to existing knowledge.

TECHNICAL NOTES: Information less broad in scope but nevertheless of importance as a contribution to existing knowledge.

\section{TECHNICAL MEMORANDUMS:}

Information receiving limited distriburion because of preliminary data, security classification, or other reasons.

CONTRACTOR REPORTS: Scientific and technical information generated under a NASA contract or grant and considered an important contribution to existing knowledge.
TECHNICAL TRANSLATIONS: Information published in a foreign language considered to merit NASA distribution in English.

SPECIAL PUBLICATIONS: Information derived from or of value to NASA activities. Publications include conference proceedings, monographs, data compilations, handbooks, sourcebooks, and special bibliographies.

TECHNOLOGY UTILIZATION PUBLICATIONS: Information on technology used by NASA that may be of particular interest in commercial and other non-aerospace applications. Publications include Tech Briefs, Technology Utilization Reports and Technology Surveys.

Details on the availability of these publications may be obtained from:

SCIENTIFIC AND TECHNICAL INFORMATION OFFICE NATIONAL AERONAUTICS AND SPACE ADMINISTRATION 